\title{
Liver transplantation for hepatocellular carcinoma - non-cancer factors and implications for improving outcome beyond standard tumor criteria
}

\author{
Arno Kornberg, Martina Schernhammer \\ Department of Surgery, Klinikum rechts der Isar, Technical University Munich, Munich D-81675, Germany. \\ Correspondence to: Dr. Arno Kornberg, Department of Surgery, Klinikum rechts der Isar, Technical University Munich, Munich D-81675, \\ Germany. E-mails: ArnoKornberg@aol.com
}

\begin{abstract}
How to cite this article: Kornberg A, Schernhammer M. Liver transplantation for hepatocellular carcinoma - non-cancer factors and implications for improving outcome beyond standard tumor criteria. Hepatoma Res 2018;4:60.

http://dx.doi.org/10.20517/2394-5079.2018.86
\end{abstract}

Received: 6 Jul 2018 First Decision: 16 Aug 2018 Revised: 27 Aug 2018 Accepted: 28 Aug 2018 Published: 29 Sep 2018

Science Editor: Guang-Wen Cao Copy Editor: Yuan-Li Wang Production Editor: Zhong-Yu Guo

\begin{abstract}
Liver transplantation (LT) is recognized as best treatment option in patients with early hepatocellular cancer (HCC) in underlying liver cirrhosis. Apart from tumor size and number implemented in the Milan criteria, which are current worldwide standards for patient selection, several biological tumor factors have been identified to affect cancer-specific outcome. In particular, grading and vascular tumor invasions were shown to correlate with aggressive biological tumor behavior and poor survival following LT. Identifying tumors with favorable biology is one important approach for expanding the pool of eligible liver recipients beyond the Milan burden limits. Improving the immunological state and condition for appropriate defense against circulating cancer cell attack may be another important prognostic aspect. Therefore, there is increasing interest in non-cancer factors related to the peritransplant period that may influence the oncological outcome by providing negative immunomodulatory actions. Considering and modulation of these non-HCC factors of prognosis might contribute in safely expanding the HCC LT selection criteria.
\end{abstract}

Keywords: Hepatocellular carcinoma, liver transplantation, tumor biology, non-cancer factors, outcome

\section{INTRODUCTION}

In the last 40 years, liver transplantation (LT) has developed as a generally accepted standard procedure in the treatment of a wide range of end-stage liver diseases. Especially liver replacement for hepatocellular carcinoma (HCC) in underlying liver cirrhosis became a phenomenal story of clinical success in oncological surgery ${ }^{[1]}$.

\footnotetext{
(@) $(0$

(C) The Author(s) 2018. Open Access This article is licensed under a Creative Commons Attribution 4.0 International License (https://creativecommons.org/licenses/by/4.0/), which permits unrestricted use, sharing, adaptation, distribution and reproduction in any medium or format, for any purpose, even commercially, as long as you give appropriate credit to the original author(s) and the source, provide a link to the Creative Commons license, and indicate if changes were made.
}

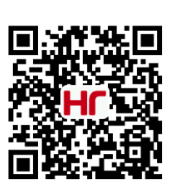


Due to cirrhosis-related portal hypertension (PH) and liver dysfunction, these patients are mostly not eligible for hepatic resection, so that only palliative treatment options have frequently been possible in former days ${ }^{[2]}$. In particular, the implementation of the so-called Milan criteria (MC) in 1996 for realizing a strict and rigid selection process based on radiographic tumor size and number (one tumor nodule $\leq 5 \mathrm{~cm}$, or up to 3 HCC nodules each $\leq 3 \mathrm{~cm}$, no macrovascular invasion) established LT as best curative treatment option in early stage HCC patients ${ }^{[3]}$. The pre-MC era was characterized by high posttransplant tumor recurrence rates and mortality, which was not acceptable in view of donor organ shortage ${ }^{[4,5]}$. In contrast, numerous validation trials have clearly shown that Milan-based LT for HCC produces excellent long-term survival rates above $70 \%$ at 5 years, which was absolutely comparable to those of other transplant indications ${ }^{[6-8]}$. Therefore, the MC have been implemented as standard selection features in large public allocation systems, such as the United Network of Organ Sharing (UNOS) and Eurotransplant ${ }^{[9,10]}$. Currently, in times of model for end-stage liver disease (MELD) score based organ allocation, priority is still given to patients with HCC meeting the MC ${ }^{[1,12]}$.

With increasing experience in rescue LT of marginal donor grafts and living donor liver transplantation (LDLT), who are both independent from MELD-based allocation rules, it became evident in recent years that the MC are too rigid and very often unjustifiably preclude patients with beyond $\mathrm{MC}$ tumors from potentially curative treatment ${ }^{[13-15]}$. In order to increase the pool of eligible transplant patients, several expanded macromorphologic tumor selection criteria have been proposed, such as the University of California San Francisco (UCSF) and the registry based Up-to-seven (UTS) criteria ${ }^{[16-18]}$. However, as shown in the metroticket concept, increasing "distance" from the MC burden limits enhances the oncological risk ${ }^{[18]}$. In addition, differences between radiologic and pathologic tumor staging additionally hamper the clinical applicability of tumor size based selection approaches ${ }^{[19,20]}$. Poor differentiation and vascular (micro/macro) invasion of the tumor were identified as most important predictors of unfavorable tumor biology in the LT setting ${ }^{[21-23]}$.

However, both histopathologic features may not adequately be assessed prior to LT by radiographic tools or by using tumor biopsy ${ }^{[24-26]}$.

The identification of patients with aggressive tumor behavior is one important clinical practice to safely expand the pool of eligible liver transplant recipients beyond the $\mathrm{MC}^{[27-29]}$. Different surrogate markers of tumor biology were shown to improve the selection process beyond the MC, such as alpha-fetoprotein (AFP) ${ }^{[30,31]}$, protein induced by Vitamin K absence II (PIVKA-II ${ }^{[32,33]}$, serological inflammatory markers [C-reactive protein (CRP); neutrophil lymphocyte ratio (NLR), platelet lymphocyte ratio (PLR) ${ }^{[34]}, 18 \mathrm{~F}$-fluorodeoxyglucose (FDG) uptake on positron emission tomography $(\mathrm{PET})^{[35,36]}$ and tumor downstaging under locoregional treatments ${ }^{[37,38]}$. Apart from that, there is increasing evidence that not only tumor-specific characteristics, but also non-cancer factors may decisively influence cancer-specific outcome. Beneficial modulations of these non-HCC related factors might probably be another useful approach to improve post-LT prognosis, since HCC recurrence is the major risk factor for poor overall survival (OS). Therefore, it was the major aim of this manuscript to review the current available clinical data on the prognostic impact of non-tumor factors on post-LT HCC recurrence and tumor-specific survival.

\section{The role of immunology and inflammation}

Immunocompetence is a major prognostic factor of outcome in cancer patients. However, a specific characteristic of neoplasia is that it induces a state of inflammation and immunosuppression, which may additionally impair prognosis ${ }^{[39]}$. Since the postulation of the link between inflammation and cancer by Virchow in 1863, important molecular mechanisms of cancer-induced pro-inflammatory response reactions have been identified. Malignant cells were shown to release inflammatory and immunosuppressive cytokines to their local environment, promoting tumor invasiveness and growth. In addition, cancer itself may induce 
systemic immunosuppression through multiple mechanisms and effector cells, such as T-cell exhaustion, T-regulatory cells, myeloid-derived suppressor cells and M2 macrophages ${ }^{[40]}$. In this context, HCC has an exceptional position, since $90 \%$ of the cases develop in underlying cirrhosis and fibrosis, which are promoted by chronic liver inflammation. Liver damage and necroinflammation induced by alcoholic disease, nonalcoholic fatty liver disease (NAFLD) and in particular by chronic viral hepatitis comprise a substantial risk of carcinogenesis ${ }^{[41,42]}$. Activation of the innate immune system, hepatocyte death with production of damage-associated molecules (DAMPs), T cell exhaustion, and upregulation of pro-inflammatory cytokines [interleukin (IL)-2, IL-7, IL-12, IL-15, IFN- $\gamma$ ] seem to be major molecular mechanisms. Thereby induced local and systemic pro-inflammatory reactions and immunosuppression lead to replication stress, DNA damage and genetic instability, which may result in development of liver cancer and impact cancer treatment ${ }^{[42,43]}$.

Another important aspect is that liver dysfunction is another important prognostic factor enhancing tumor progression. The liver plays a key role in maintaining immunocompetence. In addition to numerous other mechanisms triggered by its unique blood supply, it has an essential capability to remove gutderived microbial compounds, and hosts a great variety of innate and adaptive immune cells (sinusoidal cells, hepatic stellate cells, Kupfer cells, dendritic cells), and is able to preserve immunotolerance to nonpathogenic and inflammatory triggers. Decrease of these immunological efficacies result in a persistent upregulation of inflammatory stimuli which may promote carcinogenesis. For example, increased levels of circulating T regulatory cells were shown to be associated with increased mortality of HCC patients ${ }^{[42,43]}$.

Currently, 2 major ways of posttransplant HCC recurrence are postulated: (1) growth of pre-LT undetected extrahepatic micrometastases; and (2) engraftment of circulating tumor cells (CTC) that have been released during transplant procedures ${ }^{[44]}$. Both ways of metastasis are significantly promoted by immunological dysbalance ${ }^{[34]}$. In particular, patients with advanced HCC stages are at an extraordinary oncological risk post-LT, since macromorphologic tumor load correlates with unfavorable tumor features, such as poor grading and vascular invasion, and thereby with numbers of $\mathrm{CTC}^{[45,46]}$. A prevailing state of immunosuppression and pro-inflammation in the peritransplant period might, therefore, be particularly dangerous for advanced HCC LT patients. Consequently, recipients' factors (cirrhosis, sarcopenia), liver graft quality, surgical procedure and post-LT immunosuppressive treatment as non-cancer features affecting the immunological state have to be considered in order to safely expand the patient selection criteria.

\section{Recipients' factors}

\section{Background liver cirrhosis}

Progressive liver cirrhosis induces complex pro-inflammatory and immunosuppressive mechanisms referred to as cirrhosis-associated immune dysfunction (CAID) syndromes ${ }^{[47]}$. This may impair outcome following non-surgical treatment and hepatic resection ${ }^{[48,49]}$. This aspect has not yet been intensively studied in the LT setting so far, which may be due to the fact that most HCC transplant patients present with less severe Child A or B cirrhosis and liver dysfunction are cured by liver replacement, probably implying that CAID has no influence on posttransplant clinical course. However, some interesting recent data have shown that the extent of background native cirrhosis may affect cancer-specific outcome in the LT setting [Table 1]. Already in 2008, Ioannou et al ${ }^{[50]}$ demonstrated in a large study cohort using the UNOS database, that apart from increased AFP level, laboratory (lab.)MELD score $\geq 20$ was the most important predictor of poor post-LT survival. Again by using the UNOS dataset of 3519 liver transplants, Halazun et al ${ }^{[51]}$ identified pretransplant rising (lab.)MELD score as an independent predictor of microvascular invasion (MVI) on explant pathology, which in turn was the most important factor of poor cancer-specific outcome. Others have recently confirmed the oncological significance of background cirrhosis severity in the liver transplant setting ${ }^{[52-54]}$. In a series of 243 transplant candidates with HCC, Faitot et al ${ }^{[55]}$ demonstrated that clinically evident portal PH was 
Table 1. Impact of stage of underlying cirrhosis on post-LT HCC recurrence

\begin{tabular}{|c|c|c|c|}
\hline Ref. & $n$ & Characterization of cirrhosis severity & Impact on post-LT outcome \\
\hline Ioannou et al. ${ }^{[50]}$ & 4453 & (lab.) MELD score $\geq 20$ & $\begin{array}{l}\text { Calculated MELD score } \geq 20 \text { was the most important predictor (HR = } \\
1.61 ; 95 \% \mathrm{CI} 1.3-2.1) \text { of poor post-LT survival, along with AFP level. The } \\
\text { risk of post-LT death was almost doubled in patients with either AFP } \\
\text { level } \geq 455 \mathrm{ng} / \mathrm{mL} \text { or MELD score } \geq 20(\mathrm{HR}=1.97 ; 95 \% \mathrm{Cl} 1.6-2.5)\end{array}$ \\
\hline Halazun et al. ${ }^{[51]}$ & 3519 & Pre-LT rising (lab.) MELD score & $\begin{array}{l}\text { Rising pre-LT MELD score proved to be an independent predictor of } \\
\text { MVI on explant pathology (OR: } 1.46, \mathrm{Cl} 1.13-1.88 ; P=0.004 \text { ), which was } \\
\text { the most important factor of poor post-LT outcome }\end{array}$ \\
\hline Macdonald et al. ${ }^{[52]}$ & 1074 & (lab.) MELD score & $\begin{array}{l}\text { Calculated MELD score was identified as an independent predictor } \\
\text { of HCC recurrence or death after } \mathrm{LT}(\mathrm{HR}=1.03 ; 95 \% \mathrm{Cl} 1.01-1.05 ; P= \\
0.005) \text {, along with AFP level and donor risk index }\end{array}$ \\
\hline Komorowski et al. ${ }^{[53]}$ & 142 & (lab.) MELD score & $\begin{array}{l}\text { Apart from AFP level, pretransplant calculated MELD score turned out } \\
\text { to be an independent and significant predictor of RFS }(H R=1.16)\end{array}$ \\
\hline Foerster et al. ${ }^{[5]]}$ & 304 & (lab.) MELD score $\geq 15$ & $\begin{array}{l}\text { Calculated MELD score } \geq 15 \text { was an independent promoter of poor OS } \\
(\mathrm{HR}=1.028 ; 95 \% \mathrm{Cl} 1.002-1.053: P=0.033) \text {, with } \mathrm{HCC} \text { relapse to be } \\
\text { the major reason of mortality }\end{array}$ \\
\hline Faitot et al. ${ }^{[55]}$ & 243 & $\begin{array}{l}\text { Clinically evident portal } \\
\text { hypertension }\end{array}$ & $\begin{array}{l}\text { PH was an independent predictor of drop out from the waiting list } \\
\text { due to tumor progression }(\mathrm{OR}=2.79 ; 95 \% \mathrm{Cl} 1.02-7.69 ; P=0.04) \text {. In } \\
\text { an intent-to-treat analysis, post-LT OS was significantly lower in } \mathrm{PH} \\
\text { patients when compared to those without } \mathrm{PH}(P=0.044) \text {. However, } \\
\text { PH had no significant impact on outcome in the transplanted patients }\end{array}$ \\
\hline
\end{tabular}

AFP: alpha fetoprotein; HCC: hepatocellular carcinoma; HR: hazard ratio; LT: liver transplantation; lab: laboratory; MELD: model for end-stage liver disease; MVI: microvascular invasion; OS: overall survival; PH: portal hypertension; RFS: recurrence-free survival

an independent promoter of drop out from the waiting list due to tumor progression. In an intent-to-treat analysis, post-LT OS was significantly lower in PH patients when compared to those without PH. However, $\mathrm{PH}$ had no significant impact on outcome in the subgroup of transplanted patients [Table 1].

\section{Sarcopenia}

Nowadays, it is undoubtedly that recipients' functional status has a major prognostic impact on liver transplant recipients ${ }^{[56,57]}$. In recent years, involuntary loss of muscle mass and strength, referred to "sarcopenia", was shown to be an early predictor of frailty and poor outcome. Sarcopenia is a feared complication in consuming chronic diseases like cancer, sepsis, renal function and liver cirrhosis ${ }^{[58]}$. The pathogenesis of sarcopenia in cirrhotics is multifactorial and not fully understood. It seems to be a response to protein-energy malnutrition, metabolic catabolism, and patients' inactivity ${ }^{[59,60]}$. Although there is currently no worldwide standard measurement and index of sarcopenia, depletion of skeletal muscle mass and function estimated by crosssectional abdominal imaging were demonstrated to be a significant risk factor for wait list mortality, prolonged intensive care duration, complicated hospital stay, severe infections, metabolic syndrome and overall poor outcome in liver recipients, independent from underlying indication ${ }^{[57,61-63]}$.

The pathophysiological mechanisms accounting for such fatal complications are not completely defined. However, it seems to be quite clear that sarcopenia and in particular sarcopenic obesity negatively affect immunocompetence via pro-inflammatory cytokines and adipokines, such as IL-1, IL-6, tumor necrosis factor (TNF)- $\alpha$ and leptin. Apart from that, secretion of the myokin IL-15 is decreased, which has negative effects on growth and differentiation of $\mathrm{B}$ and $\mathrm{T}$ lymphocytes, natural killer cells, macrophages and monocytes. Thus, a persistent state of immunosuppression and inflammation arises, which is not only enhancing morbidity and mortality, but may also promote cancer development ${ }^{[64-67]}$. A large retrospective analysis including 1257 HCC patients following curative and non-curative treatments has recently identified sarcopenia as an independent promoter of mortality and HCC recurrence ${ }^{[68]}$.

Apart from that, several studies on hepatic resection have shown that risk of HCC recurrence is significantly higher in sarcopenic patients compared to those without muscle waste ${ }^{[69-72]}$. These data suggest that, with special regard to high immunosuppressive load early post-LT, sarcopenia-related depression of the 
Table 2. Impact of sarcopenia on post-LT HCC recurrence

\begin{tabular}{|c|c|c|c|}
\hline Ref. & $n$ & Surgical procedure & Multivariable impact on post-LT HCC relapse \\
\hline Itoh et $\left.a\right|^{[72]}$ & 153 & LDLT & $\begin{array}{l}\text { Low SVR was associated with poor RFS ( } P=\text { Low SVR was identified as an inde-pendent promoter } \\
\begin{array}{ll}0.01) \text { and } O S(P=0.03 .) & \text { of poor post-LDLT outcome }\end{array}\end{array}$ \\
\hline Kim et al. ${ }^{[73]}$ & 92 & LDLT & $\begin{array}{l}\text { Cumulative } \mathrm{HCC} \text { recurrence probability was Sarcopenia was identified as an independent predictor } \\
\text { significantly higher in sarcopenic vs. non- of } \mathrm{HCC} \text { relapse }(\mathrm{HR}=2.25 ; 95 \% \mathrm{Cl} 1.18-76.32 ; P= \\
\text { sarcopenic MC Out patients }(P=0.044) .0 .034) \text {, along with AFP } \\
\text { HCC recurrence rates were } 36.1 \% \text { and } 5.0 \% \\
\text { in sarcopenic and non-sarcopenic patients. }\end{array}$ \\
\hline Sharma et $a{ }^{\left[{ }^{[74]}\right.}$ & 118 & DDLT & $\begin{array}{l}\text { Overall post-LT survival was significantly Low BMD was identified as an independent predictor } \\
\text { lower in patients with low BMD compared of post- } \mathrm{LT} \text { mortality in } \mathrm{HCC} \mathrm{LT} \text { patients }(\mathrm{HR}=0.90 \text {; } \\
\text { to those with high } \mathrm{BMD}(P=0.018) \quad 95 \% \mathrm{Cl} 0.83-0.90 ; P=0.03)\end{array}$ \\
\hline
\end{tabular}

BMD: bone mineral density; Cl: confidence interval; DDLT: deceased donor LT; HCC: hepatocellular carcinoma; HR: hazard ratio; LDLT: living donor liver transplantation; MC: Milan criteria: SVR: skeletal muscle-to-visceral fat area ratio

immunocompetence may also increase the oncological risk in LT patients [Table 2]. In a subset of 153 patients following LDLT for HCC, low skeletal muscle-to-visceral fat area ratio (SVR) was shown to predict poor recurrence-free survival (RFS) and OS. In addition, low SVR was identified as an independent and significant prognostic factor for post-LT outcome ${ }^{[72]}$. Kim et al ${ }^{[73]}$ have specifically studied the impact of sarcopenia in series of 92 LDLT patients with Milan Out HCC. Tumor recurrence rate was $36.1 \%$ in sarcopenic patients and only $5 \%$ in those without muscle depletion. Apart from AFP level and MVI, sarcopenia was identified as an independent and significant promoter of HCC relapse. In series of 118 HCC LT patients, Sharma et al. ${ }^{[74]}$ were able to demonstrate that bone mineral density (BMD), an early predictor of sarcopenia, is an independent predictor of post-LT mortality, with HCC recurrence to be the most common cause of death. A recent metaanalysis by Chang et al. ${ }^{[75]}$ including 13 studies and 3111 HCC patients after curative treatments concluded that sarcopenia is correlated with both, all-cause mortality $(\mathrm{HR}=1.95$; 95\% CI 1.6-2.37) and tumor recurrence $(\mathrm{HR}=1.76 ; 95 \% \mathrm{CI} 1.27-2.45)$.

Implementing clinical features of sarcopenia in pretransplant decision making, such as the ability to walk, may significantly improve selection process and outcome ${ }^{[63]}$. In addition, perioperative interventions like intense physiotherapeutic rehabilitation and nutritional treatment are able to improve posttransplant $\mathrm{OS}^{[76-78]}$. Whether this may have a beneficial impact on oncological outcome post-LT needs to be further assessed.

Immunological dysbalance associated to malnutrition should be discovered early before sarcopenia has been established. In this context, Nagai et al. ${ }^{[78]}$ have identified peritransplant lymphopenia, which is considered a surrogate marker of immunosuppression and poor nutritrional status, as an independent predictor of both, impaired OS and RFS following LT for HCC.

\section{Liver graft injury and marginal liver grafts}

Hepatic ischemia reperfusion $(I / R)$ injury

$\mathrm{I} / \mathrm{R}$ injury to the liver graft is an inevitable process during harvesting, preservation, storage and final implantation of the organ, triggered by consecutive cold and warm ischemia periods. Severe hepatic I/ $\mathrm{R}$ damage increases the risk of posttransplant early allograft failure and immunological complications ${ }^{[79]}$. Currently, there is growing evidence from experimental studies that immune damage and pro-inflammatory response reaction induced by allograft hypoxia promote the oncological risk ${ }^{[80,81]}$. Although the precise molecular mechanisms have not yet been identified, it seems to be evident that I/R damage has cancerogenic capabilities via different molecular approaches and levels ${ }^{[82]}$. Simply put: (1) hepatic I/R produces a procancer microenvironment via microvascular disturbances, tissue hypoxia and angiogenesis; (2) resulting proinflammatory response reactions render HCC cells to be more aggressive by supporting mechanisms of cell adhesion, migration and invasion; and (3) hepatic I/R injury stimulates circulatory progenitor and immune cells to support post-LT HCC relapse. 
Table 3. Impact of cold and warm ischemia times on HCC recurrence following LT

\begin{tabular}{|c|c|c|c|}
\hline Reference & $n$ & Impact on tumor-specific outcome post-LT & $\begin{array}{l}\text { Impact on tumor-specific outcome in } \\
\text { unfavorable HCC phenotype }\end{array}$ \\
\hline Nagai et al. ${ }^{[85]}$ & 391 & $\begin{array}{l}\text { Cumulative incidence of } \mathrm{HCC} \text { recurrence was significantly higher in } \\
\mathrm{CIT}>v S .<10 \mathrm{~h}(P=0.015) \text {, and for } \mathrm{WIT}>v S .<50 \mathrm{~min}(P=0.036) \text {. } \\
\mathrm{CIT}(\mathrm{HR}=1.9 ; 95 \% \mathrm{Cl} 1.06-3.04 ; P=0.03) \text { and } \mathrm{WIT}(\mathrm{HR}=2.84 \text {, } \\
95 \% \mathrm{Cl} 1.44-4.85 ; P=0.003) \text { were both identified as independent } \\
\text { predictors of } \mathrm{HCC} \text { relapse }\end{array}$ & $\begin{array}{l}\mathrm{CIT}>10 \mathrm{~h}(\mathrm{HR}=2.6 ; 95 \% \mathrm{Cl} 1.23-5.49 ; P=0.01) \\
\text { and } \mathrm{WIT}>50 \mathrm{~min}(\mathrm{HR}=3.23 ; 95 \% \mathrm{Cl} 1.24- \\
8.38 ; P=0.01) \text { correlated independently with } \\
\mathrm{HCC} \text { recurrence in patients with vascular tumor } \\
\text { invasion but not in those without }\end{array}$ \\
\hline Kornberg et al. ${ }^{[84]}$ & 103 & $\begin{array}{l}\text { Apart from PET }+ \text { status, AFP }>400 \mathrm{ng} / \mathrm{dL} \text { and beyond } \mathrm{MC} \mathrm{HCC} \text {, } \\
\text { WIT }>50 \text { min was identified as an independent and significant } \\
\text { promoter of post-LT HCC relapse }(\mathrm{HR}=52.5 ; 95 \% \mathrm{CI} 6.0-458.1 \text {; } \\
P<0.001) \text {. RFS rates at } 1 \text { and } 3 \text { years post-LT were } 97.2 \% \text { and } \\
92.8 \% \text { in WIT } \leq 50 \text { min, and } 61.4 \% \text { and } 42.0 \% \text { in WIT }>50 \text { min, } \\
\text { respectively }(P<0.001)\end{array}$ & $\begin{array}{l}\text { In Milan In patients, HCC recurrence rate was } \\
0 \% \text { in limited but } 42.2 \% \text { in extended WIT ( } P= \\
0.001) \text {. In the Milan Out subset, } 10 \text { of } 13 \text { patients } \\
\text { with WIT }>50 \text { min }(76.9 \%) \text {, but only } 6 \text { of } 27 \\
\text { patients with WIT } \leq 50 \text { min }(22.2 \%) \text { developed } \\
\text { HCC relapse }(P=0.001) \text {. WIT was identified as } \\
\text { the only independent and significant risk factor in } \\
\text { patients with PET+ tumors (OR } 15.5 ; 95 \% \mathrm{CI} 3.0 \text { - } \\
101.5 ; P<0.001)\end{array}$ \\
\hline Grat et al. ${ }^{[85]}$ & 90 & $\begin{array}{l}\text { Apart from beyond MC tumors, pre-LT AFP level and male } \\
\text { donor sex, } \mathrm{CO}-\mathrm{LT}(\mathrm{HR}=5.88 ; 95 \% \mathrm{CI} 1.86-18.58 ; P=0.003) \\
\text { and prolonged total ischemia time }(\mathrm{HR}=1.48 ; 95 \% \mathrm{Cl} 1.06-2.07 ; \\
P=0.02) \text { were identified as independent predictors of tumor } \\
\text { recurrence }\end{array}$ & $\begin{array}{l}\text { In MC In patients, RFS rates at } 3 \text { years post- } \\
\mathrm{LT} \text { were } 100 \% \text { and } 66.7 \% \text { following PB-LT CO- } \\
\mathrm{LT}(P=0.003) \text {. Corresponding data in MC Out } \\
\text { patients were } 77.8 \% \text { and } 48.9 \%(P=0.031) \text {, } \\
\text { respectively }\end{array}$ \\
\hline Orci et al. ${ }^{[86]}$ & 9724 & $\begin{array}{l}\text { Warm ischemia time }>19 \text { min was independently associated with } \\
\mathrm{HCC} \text { recurrence }(\mathrm{HR}=4.26 ; 95 \% \mathrm{Cl} 1.20-15.1 ; P=0.025)\end{array}$ & \\
\hline
\end{tabular}

AFP: alpha fetoprotein; Cl: confidence interval; CIT: cold ischemia time; CO-LT: conventional liver transplantation; HCC: hepatocellular carcinoma; HR: hazard ratio; MC: Milan criteria; OR: odds ratio; PB-LT: piggy back liver transplantation; PET: positron emission tomography; RFS: recurrencefree survival; WIT: warm ischemia time

Transfer of these insights to the clinical transplant setting is still hampered by lack of clear standards of hepatic $\mathrm{I} / \mathrm{R}$ injury measurement ${ }^{[83,84]}$. However, there is convincing evidence that duration of cold (CIT) and warm ischemia times (WIT), which are the major triggers of I/R damage to the liver graft, correlate with risk of HCC recurrence post-LT [Table 3].

In a series of $391 \mathrm{LT}$ patients with HCC, Nagai et al. ${ }^{[85]}$ reported that CIT $>10 \mathrm{~h}$ and WIT $>50$ min were independent and significant predictors of overall and early post-LT HCC recurrence. In addition, both correlated independently with risk of tumor recurrence in patients with but not in those without vascular tumor infiltration.

Our transplant group was able to confirm the prognostic importance of ischemia time in a subset of 103 LT patients with $\mathrm{HCC}^{[84]}$. Both CIT (468 vs. $375.5 \mathrm{~min} ; P=0.001$ ) and WIT (58.4 vs. $45.7 \mathrm{~min} ; P=0.001$ ) were significantly longer in patients with compared to those without HCC relapse. Apart from PET+ status, AFP > $400 \mathrm{ng} / \mathrm{dL}$ and beyond MC tumors, WIT > 50 min was identified as an independent and significant promoter of post-LT HCC relapse ${ }^{[84]}$. RFS rates at 1 and 3 years post-LT were $97.2 \%$ and $92.8 \%$ in WIT $\leq 50 \mathrm{~min}$, and $61.4 \%$ and $42.0 \%$ in WIT $>50$ min, respectively $(P<0.001)$. In addition, WIT was able to further stratify the oncological risk in unfavorable HCC phenotype, such as PET+ tumors [Table 3].

Another interesting approach by Grat et al ${ }^{[86]}$ has focused on outcome differences between piggy back (PB) and conventional (Co) LT procedures for HCC. Among others, shorter duration of anhepatic phase and WIT were reported to be major outcome advantages of PB-LT (without clamping and replacement of the inferior caval vein) in comparison to CO-LT (including clamping and replacement of the inferior caval vein). In their series of 90 patients, RFS rates at 1, 2 and 3 years post-LT were $97.0 \%, 92.2 \%$, and $89.4 \%$ for PB-LT, but only $75.6 \%, 56.0 \%$, and $56.0 \%$ for CO-LT, respectively $(P=0.0006)$. Apart from beyond MC tumors, preLT AFP level and male donor sex, CO-LT and prolonged total ischemia time were identified as independent predictors of tumor recurrence. In addition, RFS rates were significantly different in MC In and MC Out patients when being stratified according to transplant procedure [Table 3]. 
Table 4. Impact of donor age on HCC recurrence

\begin{tabular}{|c|c|c|}
\hline Reference & $n$ & Impact on post-LT HCC recurrence \\
\hline Sharma et al. ${ }^{[95]}$ & 94 & $\begin{array}{l}\text { Median donor age was } 49 \mathrm{y} \text { and } 36 \mathrm{y} \text { in patients with and without } \mathrm{HCC} \text { relapse }(P=0.008) \text {. Along } \\
\text { with number and largest diameter of tumor nodules, donor age was identified as the only pre-LT } \\
\text { available independent risk factor of tumor recurrence }(\mathrm{HR}=1.06 ; 95 \% \mathrm{Cl} 1.02-1.10 ; P=0.002)\end{array}$ \\
\hline Vagefi et al. ${ }^{[96]}$ & 5002 (UNOS database) & $\begin{array}{l}\text { Cumulative incidence of } \mathrm{HCC} \text { recurrence at } 1-, 2-, 3-\text {, and } 4 \text {-year post-LT was } 3 \%, 5.1 \% 6.4 \% \text { and } \\
7.3 \% \text { in donors }<60 \mathrm{y}, \text { but } 4.5 \%, 8.3 \%, 10.4 \% \text { and } 11.8 \% \text { in donors }>60 \text { y }(P<0.05) \text {. Apart from } \\
\text { non-local organ sharing, donor age } \geq 60 \text { years was reported to be the only independent donor- } \\
\text { related predictor of } \mathrm{HCC} \text { recurrence }(\mathrm{HR}=1.42 ; 95 \% \mathrm{Cl} 1.09-1.84 ; P=0.009)\end{array}$ \\
\hline Orci et al. ${ }^{[87]}$ & 9724 (SRTR database) & $\begin{array}{l}\text { Donor age }>60 \text { y }(\mathrm{HR}=1.38 ; 95 \% \mathrm{Cl} 1.10-1.73 ; P=0.006) \text { was identified as an independent } \\
\text { promoter of } \mathrm{HCC} \text { relapse }\end{array}$ \\
\hline
\end{tabular}

Cl: confidence interval; HCC: hepatocellular carcinoma; HR: hazard ratio; LT: liver transplantation

In another study including 9724 liver transplant recipients of the Scientific Registry of Transplant Recipients (SRTR) database, WIT $\geq 19$ min was associated with increased risk of HCC relapse in uni- and multivariable analysis. However, the authors did not stratify data according to $\mathrm{MC}^{[87]}$.

\section{Marginal liver grafts}

The dramatic shortage of appropriate donor livers enhances the risk of patients' drop-out due to tumor progression and/or morbidity or mortality related to cirrhosis progression during waiting times. Therefore, the so-called extended criteria donor grafts (ECD) are increasingly used for decreasing the fatal discrepancy between demand and donor organ availabilities ${ }^{[8]}$. In order to avoid penalizing patients with standard criteria HCC or other indications, marginal liver grafts, such as steatotic livers, living donor liver grafts, donor livers after cardiac death (DCD) and older donor grafts are currently accepted for patients with advanced HCC stages, not at least as these patients frequently present with compensated liver function. However, such ECD livers are more susceptible to severe I/R damage, which may impair immunological and oncological outcome ${ }^{[89]}$.

\section{Steatotic donor livers}

In recent years, liver steatosis has become a serious medical issue due to growing rates of diabetes, obesity, metabolic syndrome and alcohol abuse. Consequently, the numbers of explanted, offered and finally accepted steatotic liver grafts has significantly increased in recent years. However, donor graft steatosis is associated with overall poorer outcome post- $\mathrm{LT}^{[90]}$. Based on histopathologic assessment, we distinguish between mild $(<30 \%)$, moderate (30\%-60\%) and severe ( $>60 \%$ ) liver steatosis, whereby particularly recipients of the latter are subject to an extraordinary risk of hepatic I/R damage with risk of post-LT allograft failure ${ }^{[91]}$. In an experimental setting, Orci et al ${ }^{[92]}$ have shown that I/R injury contributes to more severe intrahepatic and remote HCC recurrence with enhanced liver steatosis. Although statistical significance was lacking, Teng et al ${ }^{[93]}$ reported on a clear trend of higher HCC recurrence rates in recipients of moderate-to-severe steatotic (50\%) compared to non-steatotic grafts $(28.7 \%)$ and mild steatosis $(20.8 \%)$. In a large registry trial $(n=3007)$, Orci et al ${ }^{[87]}$ reported that graft steatosis $>60 \%$ was an independent promoter of HCC recurrence post-LT (HR $=1.65 ; 95 \%$ CI 1.03-2.64; $P=0.037)$.

\section{Donor age}

The use of elderly donor livers increases the risk of early post-LT graft loss, arterial and biliary complications, and immunological insults. Particularly presence of hepatitis $\mathrm{C}$ and prolonged ischemia times are known triggers of the negative impact of older donor grafts ${ }^{[94]}$. In recent years, there is growing evidence that donor age may also affect oncological outcome in HCC LT patients [Table 4]. In a retrospective study of 94 liver recipients, Sharma et al. ${ }^{[95]}$ were the first to identify donor age as an independent predictor of HCC recurrence, along with number of tumor lesions and size of the largest tumor diameter. Two large registry studies have subsequently confirmed the oncological importance of donor age. Apart from non-local organ sharing, donor 
Table 5. Impact of graft size on outcome in LDLT for HCC

\begin{tabular}{|c|c|c|c|}
\hline Reference & $n$ & Impact of GRWR on post-LDLT outcome & Impact of GRWR on outcome in advanced HCC \\
\hline Hu et $a{ }^{[105]}$ & 295 & $\begin{array}{l}\text { OS was significantly better in GRWR } \leq 0.8 \% \text { vs. }>0.8 \%(P= \\
0.009) \text {. RFS tended to be better in GRWR }>0.8(P=0.133) \text {. } \\
\text { GWRW }>0.8 \% \text { was identified as independent predictor of } \\
\text { poor OS ( } \mathrm{HR}=2.166 ; 95 \% \mathrm{Cl} 1.173-4.001 ; P=0.013) \text {, along } \\
\text { with vascular invasion }\end{array}$ & \\
\hline Li et al. ${ }^{[106]}$ & 597 & $\begin{array}{l}\text { RFS rates at } 1-, 3-\text { and } 5 \text { years were } 75.9 \% ; 73.3 \% \text {, and } \\
71.7 \% \text { in GRWR }<0.8 \% \text {, and } 86.4 \%, 80.8 \% \text { and } 77.9 \% \text { in } \\
\text { GRWR } \geq 0.8 \% \text {, respectively }(P=0.17) \text {. The corresponding } \\
\text { OS rates were } 87.8 \%, 80.3 \% \text { and } 78.7 \%(G R W R<0.8 \%) \text {, } \\
\text { and } 93.5 \%, 87.1 \% \text {, and } 84.1 \% \text { (GRWR } \geq 0.8 \% ; P=0.017)\end{array}$ & $\begin{array}{l}\text { The 1-, } 3 \text { - and 5-year RFS rates in MC Out patients were } 52.4 \% \text {, } \\
49.3 \% \text { and } 49.3 \% \text { in GRWR }<0.8 \% \text {, and } 76.5 \%, 68.3 \% \text {, and } \\
64.3 \% \text { in GRWR } \geq 0.8 \%(P=0.049) \text {. The corresponding OS } \\
\text { rates were } 77.1 \%, 65.3 \% \text {, and } 61.5 \% \text { (GRWR }<0.8 \%) \text {, and } 90.2 \% \text {, } \\
80.1 \% \text {, and } 77.5 \% \text { (GRWR }>0.8 \%, P=0.047) \text {. No significant } \\
\text { effect of GRWR on outcome in Milan In patients was found }\end{array}$ \\
\hline
\end{tabular}

CI: confidence interval; GRWR: graft-to-recipient body weight ratio; HR: hazard ratio; OS: overall survival; RFS: recurrence-free survival

age $\geq 60$ years was reported to be the only independent donor-related predictor of HCC recurrence in a study of 5002 patients of the UNOS database ${ }^{[96]}$. Comparably, Orci et al. ${ }^{[87]}$ reported on an independent prognostic effect of donor age $>60$ years $(\mathrm{HR}=1.38$; $95 \% \mathrm{CI} 1.10-1.73 ; P=0.006)$, when analyzing 9742 patients of the SRTR database. Adequate donor-recipient age matching was shown to improve overall long-term outcome in recipients of older donor grafts ${ }^{[97]}$. However, no data exists on the oncological impact of such a matching policy.

\section{Living donor liver grafts}

LDLT has been established as an appropriate alternative approach to fight organ shortage and, thereby, to decrease risk of drop out from the waiting list, especially in Eastern countries where the number of deceased donor liver transplants (DDLT) is significantly restricted. Allocation of these organs is not regulated by public institutions, so that the indication is independent of strict tumor size limitations. Therefore, LDLT is particularly attractive for advanced HCC patients, who may otherwise not be offered a transplant option via $\mathrm{HCC}$ exceptional MELD allocation, but rather transferred to palliative treatments ${ }^{[8,99]}$. However, apart from the donors' risks related to major hepatectomy, there are important oncological issues that have to be considered.

Liver grafts from living donors are principally small for size and, thus, exposed to an enhanced acute phase attack, which is an established promoter of cancer ${ }^{[82,100]}$. Another important oncological aspect is that fast track LDLT without HCC MELD-related waiting time may select more aggressive tumors that otherwise would have been identified and probably rejected ${ }^{[101]}$. Based on current mainly retrospective studies of the Eastern and Western transplant regions, the impact of reduced liver graft size compared to full-size donor livers on HCC recurrence remains finally unclear. One meta-analysis including 7 studies and 1310 patients did not find significant outcome differences between both transplant procedures, also when stratified according to $\mathrm{MC}^{[102]}$. In contrast, a more recent meta-analysis by Grant et al.$^{[103]}$ including 633 LDLT and 1232 DDLT patients provided evidence for reduced RFS following LDLT. Prospective multicenter studies are need, implementing standardized tumor selection criteria, comparable neoadjuvant tumor treatments and intent-to-treat outcome data, which seems to be illusionary with regard to different strategies and mentalities between Eastern and Western countries.

What seems to be equally important is, whether LDLT is principally able to produce acceptable outcome in beyond Milan patients, which by definition may also be lower than those for Milan In patients. Regarding this, it became apparent in recent years that post-LDLT 5-year RFS rates far beyond 50\% are possible in MC Out patients when implementing parameters of biological tumor aggressiveness, such as AFP, PIVKA II or PET-status ${ }^{[98,104]}$. Apart from that, size of the living related donor graft may be another important prognostic factor that should be considered [Table 5]. In a series of 295 HCC patients following LDLT, Hu et al. ${ }^{[105]}$ 
reported on significantly better 1- and 3- year OS rates in graft-to-recipient body weight ratio (GRWR) $\leq 0.8 \%$ vs. $>0.8 \%(P=0.009)$, whereas the corresponding RFS rates tended to be different $(P=0.133)$. Besides vascular invasion, GRWR was identified as the only independent and significant prognostic factor for OS. Analyzing 597 consecutive LDLT patients, Lee et al. ${ }^{[166]}$ were able to demonstrate that RFS in Milan Out patients was significantly better in GRWR $<0.8 \%(P=0.049)$ [Table 5].

\section{DCD}

In order to cope with dramatic donor organ shortage, donors after cardiac or circulatory death have been increasingly used in recent years. In comparison to LT using donors after brain death (DBD), DCD LT is characterized by repeat and prolonged WIT, higher susceptibility to I/R damage, increased rate of postLT graft failure, higher rates of re-transplants, and impaired overall outcome ${ }^{[107,108]}$. The impact of applying DCD liver grafts on the oncological outcome is currently assessed controversially. Using the SRTR database,

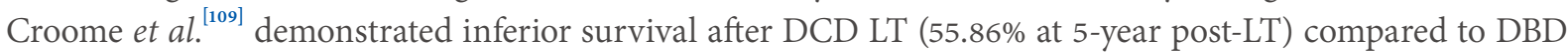
LT (63.77\% at 5-years post-LT; $P<0.001$ ) in HCC patients, without including data on tumor recurrence. More recently, several large single-center studies did not find a significant difference in cancer-related outcome between both transplant procedures ${ }^{[110,111]}$. Using the SRTR database, Oric et al. ${ }^{[87]}$ failed to identify a negative prognostic impact of DCD grafts when being compared to DBD livers. However, WIT exceeding 19 min proved to be an independent predictor of HCC relapse in the subset of DCD liver recipients $(\mathrm{HR}=4.26$; 95\%CI 1.2-15.1, $P=0.025)$.

\section{Improving cancer-specific outcome by mitigating I/R injury}

Several approaches to improve tumor-specific outcome by reducing hepatic I/R injury are currently under experimental and clinical consideration.

Orci et al. ${ }^{[12]}$ demonstrated that ischemic preconditioning prior to I/R injury reduced tumor load in an experimental setting of rat liver steatosis to an equal level as in non-steatotic control grafts. The same group recently demonstrated in another experimental study that remote ischemic preconditioning may reduce $\mathrm{I} / \mathrm{R}$ injury and modulate the gut-liver axis, finally alleviating HCC recurrence ${ }^{[113]}$.

In a retrospective clinical analysis, our transplant group was able to demonstrate that early post-LT treatment with prostaglandin E1 (PGE1) reduces hepatic I/R damage and provides beneficial immunomodulatory capabilities, finally improving cancer-specific outcome ${ }^{[114]}$. In a series of 106 HCC LT patients, RFS rates at 3- and 5-year post LT were significantly better in the PGE1-treatment group (87.9\%; 85.7\%) compared to the non-PGE1 subset $(65.3 \% ; 63.1 \% ; P=0.003)$. In addition, rate of early HCC relapse within 1 year from LT was significantly higher without PGE1 treatment ( $34 \%$ vs. 5.1\%; $P<0.001)$. When stratified according the MC, PGE1-therapy did not exert an independent prognostic impact in Milan In, whereas it was identified as a significant and independent promoter of RFS in patients with MC Out patients (HR $=5.09$; 95\%CI 1.64-15.76; $P=0.005)^{[114]}$.

The increasing use of different hypo- or normothermic extracorporeal liver perfusion systems may be another promising approach to expand the pool of transplantable ECD livers. Pre-transplant assessment of organ viability and reducing susceptibility to hepatic I/R are the suggested scope of application. In fact, the safety and feasibility of ex-situ machine preservation have already been demonstrated. First clinical trials suggested reduced morbidity and mortality in recipients of high risk organs that were pretreated with extracorporeal machine perfusion devices ${ }^{[115-117]}$. Just recently, He et al ${ }^{[118]}$ from Guangzhou transplant center presented the first case of "ischemia-free transplantation" of a severely steatotic graft by using normothermic machine perfusion without stopping blood supply, already initiated during donor liver harvesting. So far, there are no 
Table 6. Impact of intraoperative blood loss and red blood cell transfusion on post-LT outcome

\begin{tabular}{|c|c|c|c|}
\hline Reference & $n$ & Overall post-LT outcome & Cancer-specific outcome in unfavorable HCC phenotypes \\
\hline Teng et $a l^{[125]}$ & 223 & $\begin{array}{l}\text { IOBL was identified as an independent predictor of OS } \\
\text { when stratified according: } \\
\text { Milan: } H R=1.039 ; 95 \% \mathrm{Cl} 1.021-1.057 ; P<0.001 \\
\text { UCSF: } H R=1.039 ; 95 \% \mathrm{Cl} 1.002-1.057 ; P<0.001 \\
\text { Fudan: } \mathrm{HR}=1.035 ; 95 \% \mathrm{Cl} 1.018-1.052 ; P<0.001 \\
\text { Hangzhou: } \mathrm{HR}=1.020 ; 95 \% \mathrm{Cl} 1.000-1.040 ; P=0.046\end{array}$ & \\
\hline Liu et $a l^{[126]}$ & 479 & $\begin{array}{l}\text { Cumulative } 1 \text { - and } 3 \text {-year RFS rates were } 30.5 \% \text { and } \\
42.0 \% \text { in } \mathrm{IOBL} \leq 4 \mathrm{~L} \text {, and } 52.6 \% \text { and } 62.8 \% \text { in } \mathrm{IOBL}>4 \mathrm{~L} \\
(P<0.001) . \mathrm{IOBL}>4 \mathrm{~L} \text { was identified as an independent } \\
\text { promoter of overall } \mathrm{HCC} \text { recurrence }(\mathrm{HR}=2.32 ; 95 \% \mathrm{Cl} \\
1.60-3.36 ; P<0.001) \text { and early post- } \mathrm{LT} \text { (within } 1 \text { year) } \\
\text { tumor relapse }(\mathrm{HR}=2.45 ; 95 \% \mathrm{Cl} 1.64-3.66 ; P<0.001) \\
\text { Red blood cell transfusion had no prognostic impact }\end{array}$ & $\begin{array}{l}\mathrm{IOBL}>4 \mathrm{~L} \text { was identified as an independent predictor of tumor } \\
\text { recurrence in tumors with vascular invasion }(\mathrm{HR}=2.86 ; 95 \% \mathrm{Cl} \\
1.76-4.64 ; P<0.001) \text { but not in those without vascular invasion } \\
(\mathrm{HR}=1.57 ; 95 \% \mathrm{Cl} 0.87-2.85 ; P=0.138)\end{array}$ \\
\hline $\begin{array}{l}\text { Kornberg et } \\
\text { al. }{ }^{[127]}\end{array}$ & 111 & $\begin{array}{l}\text { Post-LT RFS rates at } 3 \text { and } 5 \text { years' post-LT were } 91.9 \% \\
\text { and } 91.9 \% \text { in } I O B L \leq 1500 \mathrm{~mL} \text {, but only } 43.9 \% \text { and } \\
37.1 \% \text { in } I O B L>1500 \mathrm{~mL}(P<0.001) . \text { IOBL was identified } \\
\text { as independent predictor of beneficial RFS (HR }=3.91 ; \\
95 \% \mathrm{Cl} 1.496-10.210 ; P=0.005) \text { of the entire study } \\
\text { group, whereas red blood cell transfusion had no } \\
\text { independent prognostic significance }\end{array}$ & $\begin{array}{l}\text { IOBL was identified as an independent prognostic factor for } \\
\text { RFS in Milan Out patients }(\mathrm{HR}=3.66 ; 95 \% \mathrm{Cl} 1.138-11.766 ; P= \\
0.029) \text { and } \mathrm{PET}+\text { patients }(\mathrm{HR}=4.13 ; 95 \% \mathrm{Cl} 1.482-11.524 ; P= \\
0.007) \text {. Application of }>3 \text { red blood cell units proved to be an } \\
\text { independent oncological factor in Milan Out }(\mathrm{HR}=4.98 ; 95 \% \mathrm{Cl} \\
1.442-17.185 ; P=0.011) \text { and } \mathrm{PET}+\text { patients }(\mathrm{HR}=2.98 ; 95 \% \mathrm{Cl} \\
1.071-8.280 ; P=0.037)\end{array}$ \\
\hline Nagai et al. ${ }^{[78]}$ & 391 & $\begin{array}{l}\text { Red blood cell transfusion was a strong univariate }(\mathrm{HR}= \\
1.03 ; 95 \% \mathrm{Cl} 1.01-1.05 ; P=0.001) \text { but not an independent } \\
(\mathrm{HR}=1.02 ; 95 \% \mathrm{Cl} 0.99-1.05 ; P=0.14) \text { predictor of post- } \\
\text { LT HCC recurrence }\end{array}$ & \\
\hline Seehofer et al. ${ }^{[133]}$ & 336 & $\begin{array}{l}\text { Apart from microvascular tumor invasion }(P<0.001) \text {, } \\
\text { blood transfusion was identified as the only significant } \\
\text { independent predictor of HCC recurrence }(P=0.033)\end{array}$ & $\begin{array}{l}\text { The negative impact of blood transfusions on RFS was more } \\
\text { pronounced in patients with }(P=0.023) \text { than in those without } \\
\text { vascular tumor invasion }\end{array}$ \\
\hline
\end{tabular}

Cl: confidence interval; HR: hazard ratio; IOBL: intraoperative blood loss; LT: liver transplant; OS: overall survival; PET: positron emission tomography; RFS: recurrence-free survival: UCSF: University of California San Francisco

clinical data on the oncological impact of extracorporeal machine perfusion in HCC patients.

\section{Perioperative complications}

In recent years, postoperative complications, such as bleeding, bile leakage, ascites, liver failure, infection and need of reoperation were shown to significantly impair overall and cancer-specific outcome following liver resection for $\mathrm{HCC}^{[119-121]}$. In the LT setting, surgical complications reduce the overall prognosis in HCC patients. Dai et al. ${ }^{[122]}$ have recently identified complications grade IIIA or more according to Clavien-Dindo classification as only independent predictor of poor overall outcome $(\mathrm{HR}=1.108 ; 95 \% \mathrm{CI} 1.45-34.71 ; P=0.015)$ in a series of 99 LT patients with HCC. Just recently, a study from Washington DC demonstrated in a series of 428 patients that re-operation following LT was an independent predictor of graft loss $(\mathrm{OR}=5.125 ; 95 \% \mathrm{CI}$ $1.35819 .552 ; P=0.016)^{[123]}$.

Intraoperative bleeding is still a major determinant of perioperative complications and a need of early reoperation in HCC patients. In times of increasing MELD scores and decreasing liver graft quality, blood loss remains a critical issue in LT, despite significant improvements in surgical techniques and homeostasis management ${ }^{[124]}$. There is increasing evidence that the extent of intraoperative blood loss (IOBL) may not only increase early morbidity and mortality, but also promote post-LT HCC recurrence [Table 6].

In a study including $223 \mathrm{HCC}$ LT patients, Teng et al. ${ }^{[125]}$ identified IOBL as an independent prognostic factor for poor OS, independent from the selectin criteria applied. However, the authors did not provide data on oncological outcome. The same group subsequently demonstrated in a series of 479 patients that, apart from recipients age, beyond MC status, AFP $>400 \mathrm{ng} / \mathrm{mL}$ and vascular invasion, IOBL $>4 \mathrm{~L}$ was an independent predictor of overall HCC recurrence and early post-LT (within 1 year) tumor relapse. In addition, IOBL was independently correlated with tumor recurrence in patients with but not in those without vascular invasion ${ }^{[126]}$. 
We have recently studied the impact of IOBL with a cut-off value of $1500 \mathrm{~mL}$ in 111 LT patients with HCC ${ }^{[127]}$. Post-LT RFS rates at 3 and 5 years were $91.9 \%$ and $91.9 \%$ in the low, but only $43.9 \%$ and $37.1 \%$ in the high IOBL subset $(P<0.001)$. Along with PET-status, tumor grading and AFP level, IOBL was identified as an independent predictor of cancer-specific survival. Furthermore, IOBL correlated independently with cancer relapse in unfavourable tumor phenotypes, such as Milan Out and PET+ tumors, but not in low-risk HCC ${ }^{[127]}$.

Enhanced spread of occult cancer cells, aggravation of I/R injury to the graft and induction of proinflammatory and immunosuppressive mechanisms are currently discussed as underlying cancerogenic mechanisms ${ }^{[125-129]}$. Apart from that, IOBL increases the need of red blood cell transfusion, which in turn enhances the oncological risk by induction of pro-inflammatory and immunosuppressive mechanisms ${ }^{[130,131]}$. In a meta-analysis including 5635 cases, allogeneic blood transfusion was shown to significantly increase the risk of HCC recurrence at 1,3 , and 5 years following liver resection ${ }^{[132]}$. Nagai et al. ${ }^{[78]}$ identified red blood cell transfusion as a strong univariate factor, but it had no independent prognostic significance on post-LT HCC relapse. In a retrospective analysis including 336 LT patients, Seehofer et al ${ }^{[133]}$ identified red blood cell transfusion as an independent promoter of HCC recurrence, along with vascular tumor invasion. The negative prognostic impact of blood transfusion was particularly evident in patients with vascular invasion. We have recently identified application of $>3$ red blood cell units as significant and independent prognostic factor in patients with Milan Out HCC and patients with PET-positive tumors ${ }^{[127]}$.

Whether the observed oncological risks are related to IOBL or rather to transfusion remains still unclear. In any case, limiting the risk of intraoperative bleeding and, thereby, need of red blood cell transfusion seems to be critical for improving post-LT cancer-specific outcome, particularly in patients with unfavourable tumor stages [Table 6]. As has been shown by several recent studies, intraoperative blood salvage and autologous re-transfusion do not increase the oncological risk and should increasingly be considered, in order to avoid allogeneic transfusion ${ }^{[134,135]}$.

\section{Post-transplant immunosuppression}

Post-transplant immunosuppressive treatment is recognized as a major risk factor for HCC recurrence following LT. In an immunocompetent patient, the innate immune system is able to recognize and destroy CTC. But in the transplant setting, postoperatively high immunosuppressive doses are administered in order to achieve liver graft acceptance, which depresses the natural anti-cancer properties of the immunological defence. Apart from development of de-novo cancers, this may lead to acceleration of metastatic spread, implantation and growth of circulating tumor tissue in HCC patients ${ }^{[136,137]}$.

Despite a large number of studies on this topic, the most optimal immunosuppressive concept for HCC LT patients has not yet been defined. This may be due to the fact that the vast majority of trials are of retrospective character with significant differences regarding patients' selection criteria, transplant procedure, applied immunosuppressive protocols and post-LT surveillance program. The major conclusions that can be drawn from current available data are the following: (1) early post-LT reduced exposure to calcineurin inhibitor (CNI) is an important factor of improved tumor-specific outcome post-LT [Table 7]. The CNIs cyclosporine and tacrolimus are still the main immunosuppressants used in the setting of LT. Apart from immunoregulatory properties, CNIs are also able to render oncogogenes to promote tumor cell aggressiveness and invasiveness, growth and metastasis ${ }^{[138,139]}$. As shown by an Italian group, early post-LT dose reduction of CNIs has a favourable effect on cancer-specific outcome ${ }^{[140,141]}$. In a large 2 European center study including 219 HCC patients, Rodríguez-Perálvarez et al. ${ }^{[141]}$ reported that higher exposure to CNI (mean tacrolimus trough level > $10 \mathrm{ng} / \mathrm{dL}$ or cyclosporine trough concentrations $>300 \mathrm{ng} / \mathrm{dL}$ ) within the first months post-LT enhanced the risk of HCC relapse ( $27.7 \%$ vs. $14.7 \%$ at 5 years; $P=0.007)$. Early post-LT reduced CNI exposure was identified as an 
Table 7. Immunosuppressive approaches to reduce the oncological risk after LT

\begin{tabular}{|c|c|c|c|}
\hline Reference & $n$ & Immunosuppressive approach & Impact on tumor-specific outcome \\
\hline Vivarelli et al. ${ }^{[140]}$ & 70 & $\begin{array}{l}\text { Reduced CsA exposure } \\
\quad(\leq 189.6 \mathrm{ng} / \mathrm{mL})\end{array}$ & $\begin{array}{l}\text { Mean CsA exposure was } 278.3 \pm 86.4 \mathrm{ng} / \mathrm{mL} \text { in patients with, and } \\
169.9 \pm 33.3 \mathrm{ng} / \mathrm{mL} \text { in those without } \mathrm{HCC} \text { recurrence. Reduced CsA } \\
\text { exposure was identified as the only independent predictor of HCC } \\
\text { recurrence }(P<0.001)\end{array}$ \\
\hline Vivarelli et al. ${ }^{[141]}$ & 130 & $\begin{array}{c}\text { Reduced CNI exposure } \\
(\mathrm{CsA} \leq 220 \mathrm{ng} / \mathrm{mL} ; \mathrm{Tac} \leq 10 \mathrm{ng} / \mathrm{mL})\end{array}$ & $\begin{array}{l}\text { Apart from tumor grading, } \mathrm{MVI} \text { and } \mathrm{AFP} \text { level, exposure to } \mathrm{CNI} \text { was } \\
\text { identified as the only independent predictor of } \mathrm{HCC} \text { relapse }(\mathrm{HR}= \\
4.01 ; 95 \% \mathrm{CI} 1.33-12.09 ; P=0.014)\end{array}$ \\
\hline Rodriguez-Peralvarez et al. ${ }^{[142]}$ & 219 & $\begin{array}{c}\text { Reduced CNI exposure } \\
(\mathrm{CsA} \leq 300 \mathrm{ng} / \mathrm{mL} ; \mathrm{Tac} \leq 10 \mathrm{ng} / \mathrm{mL})\end{array}$ & $\begin{array}{l}\text { Apart from tumor nodule diameter, micro- and macrovascular } \\
\text { invasion, exposure to } \mathrm{CNI} \text { was identified as independent predictor of } \\
\mathrm{HCC} \text { relapse }(\mathrm{HR}=2.82 ; 95 \% \mathrm{Cl} 1.4-5.8 ; P=0.005) \text {. Reduced } \mathrm{CNI} \\
\text { exposure resulted in a significantly better RFS in } \mathrm{MC} \text { Out patients } \\
(P=0.004) \text {, whereas there was a trend of improved tumor-specific } \\
\text { outcome in Milan Out patients }(P=0.09)\end{array}$ \\
\hline Liang et al. ${ }^{[149]}$ & 2950 & SRL-based IS & $\begin{array}{l}\text { SRL-based regimens led to improved overall survival at } 1(\mathrm{OR}=4.53 \text {; } \\
95 \% \mathrm{Cl} 2.31-8.89), 3(\mathrm{OR}=1.97 ; 95 \% \mathrm{Cl} 1.29-3.00) \text { and } 5 \text { years } \\
(\mathrm{OR}=2.47 ; 95 \% \mathrm{Cl} 0.21-0.83) \text { post- } \mathrm{LT} \text {. In addition, } \mathrm{HCC} \text { recurrence } \\
\text { rate was significantly decreased }(\mathrm{OR}=0.42 ; 95 \% \mathrm{Cl} 0.21-0.83)\end{array}$ \\
\hline Menon et $a{ }^{[150]}$ & 474 & SRL-based IS & $\begin{array}{l}\text { SRL-based IS resulted in lower recurrence rate }(\mathrm{OR}=0.3 ; 95 \% \mathrm{Cl} \\
0.16-0.55 ; P<0.001) \text {, lower recurrence-related mortality }(\mathrm{OR}=0.29 ; \\
95 \% \mathrm{Cl} 0.20-0.70 ; P=0.005) \text { and lower overall mortality }(\mathrm{OR}=0.35 ; \\
95 \% \mathrm{Cl} 0.20-0.61 ; P<0.001) \text { compared to } \mathrm{CNI} \text {-based IS }\end{array}$ \\
\hline Cholongitas et al. ${ }^{[151]}$ & 3666 & mTORi-based IS & $\begin{array}{l}\mathrm{HCC} \text { recurrence rate was significantly lower in mTORi-based IS ( } 8 \%) \\
\text { compared to } \mathrm{CNI} \text {-based protocol }(13.8 \% ; P<0.001)\end{array}$ \\
\hline Zhang et $a .^{[152]}$ & 7695 & SRL-based IS & $\begin{array}{l}\mathrm{SRL} \text {-based IS prolonged 1-year }(\mathrm{OR}=2.44 ; 95 \% \mathrm{Cl} 1.66-3.59) \text {, 3-year } \\
(\mathrm{OR}=1.67 ; 95 \% \mathrm{Cl} 1.08-2.58) \text { and } 5 \text {-year }(\mathrm{OR}=1.68 ; 95 \% \mathrm{Cl} 1.21- \\
2.33) \mathrm{OS} \text { compared to the control group. } \mathrm{SRL} \text { resulted in lower } \mathrm{HCC} \\
\text { recurrence rates }(\mathrm{OR}=1.68 ; 95 \% \mathrm{Cl} 0.37-0.98) \text {, lower recurrence- } \\
\text { related mortality }(\mathrm{OR}=0.58 ; 95 \% \mathrm{Cl} 0.42-0.81) \text { and lower overall } \\
\text { mortality (OR }=0.62 ; 95 \% \mathrm{Cl} 0.44-0.89) \text { compared to SRL-free } \\
\text { regimens }\end{array}$ \\
\hline
\end{tabular}

Cl: confidence interval; CNI: calcineurin inhibitor; CsA: cyclosprin A; HCC: hepatocellular carcinoma; IS: immunosuppression; mTORi: mammalian target of rapamycin inhibitor; OR: odds ratio; SRL: sirolimus; Tac: tacrolimus

independent predictor of favourable cancer-specific outcome. Stratified according the pathologic MC, reduced CNI exposure resulted in a significantly better RFS in Milan In patients, whereas there was a clear trend of improved RFS in Milan Out patients $(P=0.09)$, respectively ${ }^{[142]}$; and $(2)$ the protective effect of sirolimus (SRL) based immunosuppression is still inconclusive.

The use of mammalian target of rapamycine inhibitors (mTORis), such as rapamycine (SRL) and everolimus (EVL) provide anti-cancer effects by inhibiting the PI3K/AKt/mTOR pathway beyond its immunosuppressive capabilities $^{[143,144]}$. Therefore, many hopes had been placed in this immunosuppressant in recent years for reducing the risk of post-LT HCC recurrence without affecting the immunological outcome ${ }^{[145-148]}$. Several systematic reviews and meta-analyses in the past suggested a significant benefit of SRL in HCC LT patients ${ }^{[149-151]}$ [Table 7]. Just recently, Zhang et al. ${ }^{[152]}$ presented data on an updated meta-analysis including the largest number of patients $(n=7695)$ from a total of 11 studies. The authors reported that patients treated with SRL demonstrated lower recurrence rates, lower recurrence-related mortality and lower overall mortality compared to SRL-free regimens. Whether advanced HCC patients were particularly benefiting from SRL was, however, not adequately assessed. The only prospective, randomized, multicenter, open-label study recently finalized, however, did not find a significant improvement of OS and RFS beyond 5 years ${ }^{[153]}$.

Currently, several approaches to achieve recipient tolerance by IS weaning protocols in order to reduce longterm CNI-induced complications, such as hyperlipidemia, cardiovascular events, renal dysfunction and de-novo carcinoma are under consideration ${ }^{[154-157]}$. About $25 \%$ of liver transplant patients were reported to be suitable for complete IS withdrawal without increasing the risk of patient and graft loss. Probably, the application of non-invasive biomarkers predicting "operational tolerance" might permit significant reduction 
in a higher number of liver recipients ${ }^{[154]}$. As suggested in small study samples, this might be a promising ISbased approach to reduce the oncological risk in LT patients with HCC. However, larger prospective studies are needed.

\section{CONCLUSION}

As pointed out in this review, there are several important non-HCC related factors of prognosis that have to be considered in LT for HCC. However, comparability of related studies is rather limited by their mostly retrospective character and the use of different outcome variables [Tables 1-7]. Nevertheless, there is growing evidence that these non-oncological features trigger a series of unfavorable immunomodulatory processes related to inflammation and immunosuppression, and thereby promoting the oncological risk following LT. This may be particularly relevant for patients with advanced HCC stages, who are per se exposed to an increased risk of HCC recurrence. Therefore, these non-oncological factors should play an important role in individual decision making. The presented data suggest that adequate patient and graft selection, limitation of ischemia time, reduction of surgical complications and minimizing post-LT immunosuppressive drug load may be essential components for preserving immunbalance and, thereby, for improving cancer-specific survival.

Since all of these features are well-known prognostic factors that are generally affecting outcome of LT patients even without underlying malignancy, it is a particular challenge to determine the individual transplant benefit based on both tumor biology data and non-HCC variables. In this context, there is currently no applicable clinical algorithm which is implementing both aspects for risk assessment. However, what became clear from our review is that such an approach should include concepts of mitigating hepatic I/R damage not only to improve early posttransplant patient and graft survival, but to reduce the potency of metastatic tumor cell implantation and growth. Thus, the HCC patients' selection criteria might be safely expanded beyond current macromorphologic tumor burden limits.

\section{DECLARATIONS}

\section{Authors' contributions}

Conceived the study, analyzed data and wrote the manuscript: Kornberg A

Analyzed data and revised the manuscript: Schernhammer M

\section{Availability of data and materials}

Not applicable.

\section{Financial support and sponsorship}

None.

\section{Conflicts of interest}

Both authors declared that there are no conflicts of interest.

\section{Ethical approval and consent to participate}

Not applicable.

\section{Consent for publication}

Not applicable.

\section{Copyright}

(c) The Author(s) 2018. 


\section{REFERENCES}

1. Bhardwaj N, Perera MT, Silva MA. Current treatment approaches to HCC with a special consideration to transplantation. J Transplant 2016;2016:7926264.

2. Sapisochin G, Bruix J. Liver transplantation for hepatocellular carcinoma: outcomes and novel surgical approaches. Nat Rev Gastroenterol Hepatol 2017;14:203-17.

3. Mazzaferro V, Regalia E, Doci R, Andreola S, Pulvirenti A, Bozzetti F, Montalto F, Ammatuna M, Morabito A, Gennari L. Liver transplantation for the treatment of small hepatocellular carcinomas in patients with cirrhosis. N Engl J Med 1996;334:693-9.

4. McPeake JR, O’Grady JG, Zaman S, Portmann B, Wight DG, Tan KC, Calne RY, Williams R. Liver transplantation for primary hepatocellular carcinoma: tumor size and number determine outcome. J Hepatol 1993;18:226-34.

5. Iwatsuki S, Starzl TE. Role of liver transplantation in the treatment of hepatocellular carcinoma. Semin Surg Oncol 1993;9:337-40.

6. Mazzaferro V, Chun YS, Poon RT, Schwartz ME, Yao FY, Marsh JW, Bhoori S, Lee SG. Liver transplantation for hepatocellular carcinoma. Ann Surg Oncol 2008;15:1001-7.

7. De Giorgio M, Vezzoli S, Cohen E, Armellini E, Lucà MG, Verga G, Pinelli D, Nani R, Valsecchi MG, Antolini L, Colledan M, Fagiuoli S, Strazzabosco M. Prediction of progression-free survival in patients presenting with hepatocellular carcinoma within the Milan criteria. Liver Transpl 2010;16:503-12.

8. Hoffmann K, Hinz U, Hillebrand N, Radeleff BA, Ganten TM, Schirmacher P, Schmidt J, Büchler MW, Schemmer P. Risk factors of survival after liver transplantation for HCC: a multivariate single-center analysis. Clin Transplant 2011;25:E541-51.

9. Taniguchi M. Liver transplantation in the MELD era--analysis of the OPTN/UNOS registry. Clin Transpl 2012;41-65.

10. Adler M, De Pauw F, Vereerstraeten P, Fancello A, Lerut J, Starkel P, Van Vlierberghe H, Troisi R, Donckier V, Detry O, Delwaide J, Michielsen P, Chapelle T, Pirenne J, Nevens F. Outcome of patients with hepatocellular carcinoma listed for liver transplantation within the Eurotransplant allocation system. Liver Transpl 2008;14:526-33.

11. Ferre C, Lledó JL, Aguilera L, Garcia-Paredes A, Rodríguez-Santiago E, Graus J, García-González M, Nuño J, López-Buenadicha A, López-Hervás P, Rodríguez-Gandía M, Gea F, Albillos A. Current allocation policy is favorable for patients with hepatocellular carcinoma waiting for liver transplantation. Dig Liver Dis 2018;pii: S1590-8658:30721-7.

12. Massie AB, Caffo B, Gentry SE, Hall EC, Axelrod DA, Lentine KL, Schnitzler MA, Gheorghian A, Salvalaggio PR, Segev DL. MELD exceptions and rates of waiting list outcomes. Am J Transplant 2011;11:2362-71.

13. Facciuto ME, Singh MK, Katta U, Samaniego S, Sharma J, Rodriguez-Davalos M, Sheiner P, Kim-Schluger L, Wolf DC. Liver transplantation for hepatocellular carcinoma: defining the impact of using extended criteria liver allografts. Transplantation 2011;92:446-52.

14. Choi HJ, Kim DG, Na GH, Hong TH, You YK. Extended criteria for living donor liver transplantation in patients with advanced hepatocellular carcinoma. Transplant Proc 2012;44:399-402.

15. Volk ML, Marrero JA, Lok AS, Ubel PA. Who decides? Living donor liver transplantation for advanced hepatocellular carcinoma. Transplantation 2006;82:1136-9.

16. Yao FY, Ferrell L, Bass NM, Bacchetti P, Ascher NL, Roberts JP. Liver transplantation for hepatocellular carcinoma: comparison of the proposed UCSF criteria with the Milan criteria and the Pittsburgh modified TNM criteria. Liver Transpl 2002;8:765-74.

17. Decaens T, Roudot-Thoraval F, Hadni-Bresson S, Meyer C, Gugenheim J, Durand F, Bernard PH, Boillot O, Sulpice L, Calmus Y, Hardwigsen J, Ducerf C, Pageaux GP, Dharancy S, Chazouilleres O, Cherqui D, Duvoux C. Impact of UCSF criteria according to pre- and post-OLT tumor features: analysis of 479 patients listed for HCC with a short waiting time. Liver Transpl 2006;12:1761-9.

18. Mazzaferro V, Llovet JM, Miceli R, Bhoori S, Schiavo M, Mariani L, Camerini T, Roayaie S, Schwartz ME, Grazi GL, Adam R, Neuhaus P, Salizzoni M, Bruix J, Forner A, De Carlis L, Cillo U, Burroughs AK, Troisi R, Rossi M, Gerunda GE, Lerut J, Belghiti J, Boin I, Gugenheim J, Rochling F, Van Hoek B, Majno P; Metroticket Investigator Study Group. Predicting survival after liver transplantation in patients with hepatocellular carcinoma beyond the Milan criteria: a retrospective, exploratory analysis. Lancet Oncol 2009;10:35-43.

19. Ecker BL, Hoteit MA, Forde KA, Hsu CC, Reddy KR, Furth EE, Siegelman ES, Habibollahi P, Ben-Josef E, Porrett PM, Abt PL, Shaked A, Olthoff KM, Levine MH. Patterns of discordance between pretransplant imaging stage of hepatocellular carcinoma and posttransplant pathologic stage: a contemporary appraisal of the Milan criteria. Transplantation 2018;102:648-55.

20. Shah SA, Tan JC, McGilvray ID, Cattral MS, Cleary SP, Levy GA, Greig PD, Grant DR. Accuracy of staging as a predictor for recurrence after liver transplantation for hepatocellular carcinoma. Transplantation 2006;81:1633-9.

21. Pecchi A, Besutti G, De Santis M, Del Giovane C, Nosseir S, Tarantino G, Di Benedetto F, Torricelli P. Post-transplantation hepatocellular carcinoma recurrence: patterns and relation between vascularity and differentiation degree. World J Hepatol 2015;7:276-84.

22. Li WX, Li Z, Gao PJ, Gao J, Zhu JY. Histological differentiation predicts post-liver transplantation survival time. Clin Res Hepatol Gastroenterol. 2014;38:201-8.

23. Zhang X, Li J, Shen F, Lau WY. Significance of presence of microvascular invasion in specimens obtained after surgical treatment of hepatocellular carcinoma. J Gastroenterol Hepatol 2018;33:347-54.

24. Grąt M, Stypułkowski J, Patkowski W, Bik E, Krasnodębski M, Wronka KM, Lewandowski Z, Wasilewicz M, Grąt K, Masior Ł, Ligocka J, Krawczyk M. Limitations of predicting microvascular invasion in patients with hepatocellular cancer prior to liver transplantation. Sci Rep 2017;7:39881.

25. Chandarana H, Robinson E, Hajdu CH, Drozhinin L, Babb JS, Taouli B. Microvascular invasion in hepatocellular carcinoma: is it predictable with pretransplant MRI? AJR Am J Roentgenol 2011;196:1083-9.

26. Pawlik TM, Gleisner AL, Anders RA, Assumpcao L, Maley W, Choti MA. Preoperative assessment of hepatocellular carcinoma tumor grade using needle biopsy: implications for transplant eligibility. Ann Surg 2007;245:435-42.

27. Lee HW, Song GW, Lee SG, Kim JM, Joh JW, Han DH, Kim SI, Kim SH, Kim DS, Cho JY, Suh KS. Patient selection by tumor markers in liver transplantation for advanced hepatocellular carcinoma. Liver Transpl 2018; doi: 10.1002/1t.25056.

28. Viveiros A, Zoller H, Finkenstedt A. Hepatocellular carcinoma: when is liver transplantation oncologically futile? Transl Gastroenterol 
Hepatol 2017;2:63.

29. El-Fattah MA. Hepatocellular carcinoma biology predicts survival outcome after liver transplantation in the USA. Indian J Gastroenterol 2017;36:117-25.

30. Sapisochin G, Goldaracena N, Laurence JM, Dib M, Barbas A, Ghanekar A, Cleary SP, Lilly L, Cattral MS, Marquez M, Selzner M, Renner E, Selzner N, McGilvray ID, Greig PD, Grant DR. The extended Toronto criteria for liver transplantation in patients with hepatocellular carcinoma: a prospective validation study. Hepatology 2016;64:2077-88.

31. Andreou A, Bahra M, Guel S, Struecker B, Sauer IM, Klein F, Pascher A, Pratschke J, Seehofer D. Tumor DNA index and $\alpha$-fetoprotein level define outcome following liver transplantation for advanced hepatocellular carcinoma. Eur Surg Res 2015;55:302-18.

32. Kim SH, Moon DB, Kim WJ, Kang WH, Kwon JH, Jwa EK, Cho HD, Ha SM, Chung YK, Lee SG. Preoperative prognostic values of $\alpha$-fetoprotein (AFP) and protein induced by Vitamin K absence or antagonist-II (PIVKA-II) in patients with hepatocellular carcinoma for living donor liver transplantation. Hepatobiliary Surg Nutr 2016;5:461-9.

33. Chaiteerakij R, Zhang X, Addissie BD, Mohamed EA, Harmsen WS, Theobald PJ, Peters BE, Balsanek JG, Ward MM, Giama NH, Moser CD, Oseini AM, Umeda N, Venkatesh S, Harnois DM, Charlton MR, Yamada H, Satomura S, Algeciras-Schimnich A, Snyder MR, Therneau TM, Roberts LR. Combinations of biomarkers and Milan criteria for predicting hepatocellular carcinoma recurrence after liver transplantation. Liver Transpl 2015;21:599-606.

34. Cescon M, Bertuzzo VR, Ercolani G, Ravaioli M, Odaldi F, Pinna AD. Liver transplantation for hepatocellular carcinoma: role of inflammatory and immunological state on recurrence and prognosis. World J Gastroenterol 2013;19:9174-82.

35. Hsu CC, Chen CL, Wang CC, Lin CC, Yong CC, Wang SH, Liu YW, Lin TL, Lee WF, Lin YH, Chan YC, Wu YJ, Eng HL, Cheng YF. Combination of FDG-PET and UCSF criteria for predicting HCC recurrence after living donor liver transplantation. Transplantation 2016;100:1925-32.

36. Kornberg A, Küpper B, Tannapfel A, Büchler P, Krause B, Witt U, Gottschild D, Friess H. Patients with non-[18 F]fludeoxyglucose-avid advanced hepatocellular carcinoma on clinical staging may achieve long-term recurrence-free survival after liver transplantation. Liver Transpl 2012;18:53-61.

37. Chapman WC, Garcia-Aroz S, Vachharajani N, Fowler K, Saad N, Lin Y, Wellen J, Tan B, Khan AS, Doyle MB. Liver transplantation for advanced hepatocellular carcinoma after downstaging without up-front stage restrictions. J Am Coll Surg 2017;224:610-21.

38. Agopian VG, Morshedi MM, McWilliams J, Harlander-Locke MP, Markovic D, Zarrinpar A, Kaldas FM, Farmer DG, Yersiz H, Hiatt JR, Busuttil RW. Complete pathologic response to pretransplant locoregional therapy for hepatocellular carcinoma defines cancer cure after liver transplantation: analysis of 501 consecutively treated patients. Ann Surg 2015;262:536-45.

39. Fernandes JV, Cobucci RN, Jatobá CA, Fernandes TA, de Azevedo JW, de Araújo JM. The role of the mediators of inflammation in cancer development. Pathol Oncol Res 2015;21:527-34.

40. Horiguchi H, Loftus TJ, Hawkins RB, Raymond SL, Stortz JA, Hollen MK, Weiss BP, Miller ES, Bihorac A, Larson SD, Mohr AM, Brakenridge SC, Tsujimoto H, Ueno H, Moore FA, Moldawer LL, Efron PA; Sepsis and Critical Illness Research Center Investigators. Innate immunity in the persistent inflammation, immunosuppression, and catabolism syndrome and its implications for therapy. Front Immunol 2018;9:595.

41. Yu LX, Ling Y, Wang HY. Role of nonresolving inflammation in hepatocellular carcinoma development and progression. NPJ Precis Oncol 2018;2:6.

42. Ringelhan M, Pfister D, O’Connor T, Pikarsky E, Heikenwalder M. The immunology of hepatocellular carcinoma. Nat Immunol 2018;19:222-32.

43. Ghouri YA, Mian I, Rowe JH. Review of hepatocellular carcinoma: epidemiology, etiology, and carcinogenesis. J Carcinog 2017;16:1.

44. Toso C, Mentha G, Majno P. Liver transplantation for hepatocellular carcinoma: five steps to prevent recurrence. Am J Transplant 2011;11:2031-5.

45. Shirabe K, Toshima T, Kimura K, Yamashita Y, Ikeda T, Ikegami T, Yoshizumi T, Abe K, Aishima S, Maehara Y. New scoring system for prediction of microvascular invasion in patients with hepatocellular carcinoma. Liver Int 2014;34:937-41.

46. Sun C, Liao W, Deng Z, Li E, Feng Q, Lei J, Yuan R, Zou S, Mao Y, Shao J, Wu L, Zhang C. The diagnostic value of assays for circulating tumor cells in hepatocellular carcinoma: a meta-analysis. Medicine (Baltimore) 2017;96:e7513.

47. Noor MT, Manoria P. Immune dysfunction in cirrhosis. J Clin Transl Hepatol 2017;5:50-8.

48. Wang Q, Fiel MI, Blank S, Luan W, Kadri H, Kim KW, Manizate F, Rosenblatt AG, Labow DM, Schwartz ME, Hiotis SP. Impact of liver fibrosis on prognosis following liver resection for hepatitis B-associated hepatocellular carcinoma. Br J Cancer 2013;109:573-81.

49. Sasaki K, Shindoh J, Margonis GA, Nishioka Y, Andreatos N, Sekine A, Hashimoto M, Pawlik TM. Effect of background liver cirrhosis on outcomes of hepatectomy for hepatocellular carcinoma. JAMA Surg 2017;152:e165059.

50. Ioannou GN, Perkins JD, Carithers RL Jr. Liver transplantation for hepatocellular carcinoma: impact of the MELD allocation system and predictors of survival. Gastroenterology 2008;134:1342-51.

51. Halazun K, Przybyszewski E, Verna E, Samstein B, Fox A, Brown R, Emond J. The influence of rising Lab MELD on vascular invasion in HCC. Available from: https://atcmeetingabstracts.com/abstract/the-influence-of-rising-lab-meld-on-vascular-invasion-in-hcc/. [Last accessed on 26 Sep 2018]

52. Macdonald B, Sewell JL, Harper AM, Roberts JP, Yao FY. Liver transplantation for hepatocellular carcinoma: analysis of factors predicting outcome in 1074 patients in OPTN Region 5. Clin Transplant 2015;29:506-12.

53. Komorowski AL, Hsu CC, Julka KD, Vasavada B, Lin CC, Wang CC, Chen CL. AFP role in predicting recurrence of hepatocellular carcinoma after living donor liver transplantation in HCV patients. Neoplasma 2018;65:455-60.

54. Foerster F, Mittler J, Darstein F, Heise M, Marquardt JU, Wörns MA, Weinmann A, Sälter L, Hoppe-Lotichius M, Heinrich S, Kloeckner R, Pitton MB, Schattenberg JM, Sprinzl MF, Düber C, Otto G, Lang H, Galle PR, Zimmermann T. Recipient liver function before liver transplantation influences post-transplantation survival in patients with HCC. Eur J Intern Med 2018;55:57-65.

55. Faitot F, Allard MA, Pittau G, Ciacio O, Adam R, Castaing D, Cunha AS, Pelletier G, Cherqui D, Samuel D, Vibert E. Impact of clinically 
evident portal hypertension on the course of hepatocellular carcinoma in patients listed for liver transplantation. Hepatology 2015;62:17987.

56. Lai JC, Volk ML, Strasburg D, Alexander N. Performance-based measures associate with frailty in patients with end-stage liver disease. Transplantation 2016;100:2656-60.

57. Lai JC, Feng S, Terrault NA, Lizaola B, Hayssen H, Covinsky K. Frailty predicts waitlist mortality in liver transplant candidates. Am J Transplant 2014;14:1870-9.

58. Chang SF, Lin PL. Systematic literature review and meta-analysis of the Association of Sarcopenia with Mortality. Worldviews Evid Based Nurs 2016;13:153-62.

59. Laube R, Wang H, Park L, Heyman JK, Vidot H, Majumdar A, Strasser SI, McCaughan GW, Liu K. Frailty in advanced liver disease. Liver Int. 2018; doi: 10.1111/liv.13917.

60. Ebadi M, Montano-Loza AJ. Insights on clinical relevance of sarcopenia in patients with cirrhosis and sepsis. Liver Int 2018;38:786-8.

61. Kahn J, Wagner D, Homfeld N, Müller H, Kniepeiss D, Schemmer P. Both sarcopenia and frailty determine suitability of patients for liver transplantation-a systematic review and meta-analysis of the literature. Clin Transplant 2018;32:e13226.

62. Chae MS, Moon KU, Jung JY, Choi HJ, Chung HS, Park CS, Lee J, Choi JH, Hong SH. Perioperative loss of psoas muscle is associated with patient survival in living donor liver transplantation. Liver Transpl 2018;24:623-33.

63. Kaido T, Hamaguchi Y, Uemoto S. Sarcopenia plays a crucial role in liver transplantation. Hepatobiliary Surg Nutr 2017;6:434-6.

64. Wilson D, Jackson T, Sapey E, Lord JM. Frailty and sarcopenia: the potential role of an aged immune system. Ageing Res Rev 2017;36:110.

65. Brzeszczyńska J, Meyer A, McGregor R, Schilb A, Degen S, Tadini V, Johns N, Langen R, Schols A, Glass DJ, Roubenoff R, Ross JA, Fearon $\mathrm{KCH}$, Greig CA, Jacobi C. Alterations in the in vitro and in vivo regulation of muscle regeneration in healthy ageing and the influence of sarcopenia. J Cachexia Sarcopenia Muscle 2018;9:93-105.

66. Angulo J, El Assar M, Rodríguez-Mañas L. Frailty and sarcopenia as the basis for the phenotypic manifestation of chronic diseases in older adults. Mol Aspects Med 2016;50:1-32.

67. Pistilli EE, Siu PM, Alway SE. Interleukin-15 responses to aging and unloading-induced skeletal muscle atrophy. Am J Physiol Cell Physiol 2007;292:1298-304

68. Fujiwara N, Nakagawa H, Kudo Y, Tateishi R, Taguri M, Watadani T, Nakagomi R, Kondo M, Nakatsuka T, Minami T, Sato M, Uchino K, Enooku K, Kondo Y, Asaoka Y, Tanaka Y, Ohtomo K, Shiina S, Koike K. Sarcopenia, intramuscular fat deposition, and visceral adiposity independently predict the outcomes of hepatocellular carcinoma. J Hepatol 2015;63:131-40.

69. Shirai H, Kaido T, Hamaguchi Y, Kobayashi A, Okumura S, Yao S, Yagi S, Kamo N, Taura K, Okajima H, Uemoto S. Preoperative low muscle mass and low muscle quality negatively impact on pulmonary function in patients undergoing hepatectomy for hepatocellular carcinoma. Liver Cancer 2018;7:76-89.

70. Yabusaki N, Fujii T, Yamada S, Suzuki K, Sugimoto H, Kanda M, Nakayama G, Koike M, Fujiwara M, Kodera Y. Adverse impact of low skeletal muscle index on the prognosis of hepatocellular carcinoma after hepatic resection. Int J Surg 2016;30:136-42.

71. Voron T, Tselikas L, Pietrasz D, Pigneur F, Laurent A, Compagnon P, Salloum C, Luciani A, Azoulay D. Sarcopenia impacts on short- and long-term results of hepatectomy for hepatocellular carcinoma. Ann Surg 2015;261:1173-83.

72. Itoh S, Yoshizumi T, Kimura K, Okabe H, Harimoto N, Ikegami T, Uchiyama H, Shirabe K, Nishie A, Maehara Y. Effect of sarcopenic obesity on outcomes of living-donor liver transplantation for hepatocellular carcinoma. Anticancer Res 2016;36:3029-34.

73. Kim YR, Park S, Han S, Ahn JH, Kim S, Sinn DH, Jeong WK, Ko JS, Gwak MS, Kim GS. Sarcopenia as a predictor of post-transplant tumor recurrence after living donor liver transplantation for hepatocellular carcinoma beyond the Milan criteria. Sci Rep 2018;8:7157.

74. Sharma P, Parikh ND, Yu J, Barman P, Derstine BA, Sonnenday CJ, Wang SC, Su GL. Bone mineral density predicts posttransplant survival among hepatocellular carcinoma liver transplant recipients. Liver Transpl 2016;22:1092-8.

75. Chang KV, Chen JD, Wu WT, Huang KC, Hsu CT, Han DS. Association between loss of skeletal muscle mass and mortality and tumor recurrence in hepatocellular carcinoma: a systematic review and meta-analysis. Liver Cancer 2018;7:90-103.

76. Kamo N, Kaido T, Hamaguchi Y, Uozumi R, Okumura S, Kobayashi A, Shirai H, Yagi S, Okajima H, Uemoto S. Impact of enteral nutrition with an immunomodulating diet enriched with hydrolyzed whey peptide on infection after liver transplantation. World J Surg 2018; doi: 10.1007/s00268-018-4680-0.

77. Duarte-Rojo A, Ruiz-Margáin A, Montaño-Loza AJ, Macías-Rodríguez RU, Ferrando A, Kim WR. Exercise and physical activity for patients with end-stage liver disease: Improving functional status and sarcopenia while on the transplant waiting list. Liver Transpl 2018;24:122-39.

78. Nagai S, Abouljoud MS, Kazimi M, Brown KA, Moonka D, Yoshida A. Peritransplant lymphopenia is a novel prognostic factor in recurrence of hepatocellular carcinoma after liver transplantation. Transplantation 2014;97:694-701.

79. Zhai Y, Petrowsky H, Hong JC, Busuttil RW, Kupiec-Weglinski JW. Ischaemia-reperfusion injury in liver transplantation--from bench to bedside. Nat Rev Gastroenterol Hepatol 2013;10:79-89.

80. Wang S, Yang FJ, Wang X, Zhou Y, Dai B, Han B, Ma HC, Ding YT, Shi XL. PARP-1 promotes tumor recurrence after warm ischemic liver graft transplantation via neutrophil recruitment and polarization. Oncotarget 2017;8:88918-33.

81. Li CX, Ling CC, Shao Y, Xu A, Li XC, Ng KT, Liu XB, Ma YY, Qi X, Liu H, Liu J, Yeung OW, Yang XX, Liu QS, Lam YF, Zhai Y, Lo CM, Man K. CXCL10/CXCR3 signaling mobilized-regulatory T cells promote liver tumor recurrence after transplantation. J Hepatol 2016;65:944-52.

82. Li CX, Man K, Lo CM. The impact of liver graft injury on cancer recurrence posttransplantation. Transplantation 2017;101:2665-70.

83. Grąt M, Krawczyk M, Wronka KM, Stypułkowski J, Lewandowski Z, Wasilewicz M, Krawczyk P, Grąt K, Patkowski W, Zieniewicz $\mathrm{K}$. Ischemia-reperfusion injury and the risk of hepatocellular carcinoma recurrence after deceased donor liver transplantation. Sci Rep 2018;8:8935.

84. Kornberg A, Witt U, Kornberg J, Friess H, Thrum K. Extended ischemia times promote risk of HCC recurrence in liver transplant patients. 
Dig Dis Sci 2015;60:2832-9.

85. Nagai S, Yoshida A, Facciuto M, Moonka D, Abouljoud MS, Schwartz ME, Florman SS. Ischemia time impacts recurrence of hepatocellular carcinoma after liver transplantation. Hepatology 2015;61:895-904.

86. Grąt M, Kornasiewicz O, Lewandowski Z, Skalski M, Zieniewicz K, Pączek L, Krawczyk M. The impact of surgical technique on the results of liver transplantation in patients with hepatocellular carcinoma. Ann Transplant 2013;18:448-59.

87. Orci LA, Berney T, Majno PE, Lacotte S, Oldani G, Morel P, Mentha G, Toso C. Donor characteristics and risk of hepatocellular carcinoma recurrence after liver transplantation. Br J Surg 2015;102:1250-7.

88. Vodkin I, Kuo A. Extended criteria donors in liver transplantation. Clin Liver Dis 2017;21:289-301.

89. Nemes B, Gámán G, Polak WG, Gelley F, Hara T, Ono S, Baimakhanov Z, Piros L, Eguchi S. Extended-criteria donors in liver transplantation part II: reviewing the impact of extended-criteriadonors on the complications and outcomes of liver transplantation. Expert Rev Gastroenterol Hepatol 2016;10:841-59.

90. Vinaixa C, Selzner N, Berenguer M. Fat and liver transplantation: clinical implications. Transpl Int 2018;31:828-37.

91. Tashiro H, Kuroda S, Mikuriya Y, Ohdan H. Ischemia-reperfusion injury in patients with fatty liver and the clinical impact of steatotic liver on hepatic surgery. Surg Today 2014;44:1611-25.

92. Orci LA, Lacotte S, Oldani G, Slits F, De Vito C, Crowe LA, Rubbia-Brandt L, Vallée JP, Morel P, Toso C. Effect of ischaemic preconditioning on recurrence of hepatocellular carcinoma in an experimental model of liver steatosis. Br J Surg 2016;103:417-26.

93. Teng da H, Zhu ZJ, Zheng H, Deng YL, Sun LY, Pan C, Liu YH, Song HL, Shen ZY. Effect of steatosis donor liver transplantation on hepatocellular carcinoma recurrence: experience at a single institution. Hepatogastroenterology 2012;59:858-62.

94. Lué A, Solanas E, Baptista P, Lorente S, Araiz JJ, Garcia-Gil A, Serrano MT. How important is donor age in liver transplantation? World J Gastroenterol 2016;22:4966-76.

95. Sharma P, Welch K, Hussain H, Pelletier SJ, Fontana RJ, Marrero J, Merion RM. Incidence and risk factors of hepatocellular carcinoma recurrence after liver transplantation in the MELD era. Dig Dis Sci 2012;57:806-12.

96. Vagefi PA, Dodge JL, Yao FY, Roberts JP. Potential role of the donor in hepatocellular carcinoma recurrence after liver transplantation. Liver Transpl 2015;21:187-94.

97. Ghinolfi D, Lai Q, Pezzati D, De Simone P, Rreka E, Filipponi F. Use of elderly donors in liver transplantation: a paired-match analysis at a single center. Ann Surg 2018;268:325-31.

98. Pinheiro RS, Waisberg DR, Nacif LS, Rocha-Santos V, Arantes RM, Ducatti L, Martino RB, Lai Q, Andraus W, D’Albuquerque LAC. Living donor liver transplantation for hepatocellular cancer: an (almost) exclusive Eastern procedure? Transl Gastroenterol Hepatol 2017;2:68.

99. Cho Y, Lee JH, Lee DH, Cho EJ, Yu SJ, Yi NJ, Lee KW, Kim YJ, Yoon JH, Suh KS. Comparison of treatment outcome between living donor liver transplantation and sorafenib for patients with hepatocellular carcinoma beyond the Milan criteria. Oncotarget 2017;8:47555-64.

100. Chan SC. Section 2. Small-for-size liver graft and hepatocellular carcinoma recurrence. Transplantation 2014;97 Suppl 8:S7-10.

101. Llovet JM, Pavel M, Rimola J, Diaz MA, Colmenero J, Saavedra-Perez D, Fondevila C, Ayuso C, Fuster J, Ginès P, Bruix J, GarciaValdecasas JC. Pilot study of living donor liver transplantation for patients with hepatocellular carcinoma exceeding Milan criteria (Barcelona Clinic Liver Cancer extended criteria). Liver Transpl 2018;24:369-79.

102. Liang W, Wu L, Ling X, Schroder PM, Ju W, Wang D, Shang Y, Kong Y, Guo Z, He X. Living donor liver transplantation versus deceased donor liver transplantation for hepatocellular carcinoma: a meta-analysis. Liver Transpl 2012;18:1226-36.

103. Grant RC, Sandhu L, Dixon PR, Greig PD, Grant DR, McGilvray ID. Living vs. deceased donor liver transplantation for hepatocellular carcinoma: a systematic review and meta-analysis. Clin Transplant 2013;27:140-7.

104. Kim SH, Moon DB, Kim WJ, Kang WH, Kwon JH, Jwa EK, Cho HD, Ha SM, Chung YK, Lee SG. Preoperative prognostic values of $\alpha$-fetoprotein (AFP) and protein induced by Vitamin K absence or antagonist-II (PIVKA-II) in patients with hepatocellular carcinoma for living donor liver transplantation. Hepatobiliary Surg Nutr 2016;5:461-9.

105. Hu Z, Zhong X, Zhou J, Xiang J, Li Z, Zhang M, Wu J, Jiang W, Zheng S. Smaller grafts do not imply early recurrence in recipients transplanted for hepatocellular carcinoma: a Chinese experience. Sci Rep 2016;6:26487.

106. Lee EC, Kim SH, Shim JR, Park SJ. Small-for-size grafts increase recurrence of hepatocellular carcinoma in liver transplantation beyond milan criteria. Liver Transpl 2018;24:35-43.

107. Eren EA, Latchana N, Beal E, Hayes D Jr, Whitson B, Black SM. Donations after circulatory death in liver transplant. Exp Clin Transplant 2016;14:463-70.

108. Sutherland AI, Oniscu GC. Challenges and advances in optimizing liver allografts from donation after circulatory deathdonors. J Nat Sci Biol Med 2016;7:10-5.

109. Croome KP, Wall W, Chandok N, Beck G, Marotta P, Hernandez-Alejandro R. Inferior survival in liver transplant recipients with hepatocellular carcinoma receiving donation aftercardiac death liver allografts. Liver Transpl $2013 ; 19: 1214-23$.

110. Croome KP, Lee DD, Burns JM, Musto K, Paz D, Nguyen JH, Perry DK, Harnois DM, Taner CB. The use of donation after cardiac death allografts does not increase recurrence of hepatocellular carcinoma. Am J Transplant 2015;15:2704-11.

111. Khorsandi SE, Yip VS, Cortes M, Jassem W, Quaglia A, O’Grady J, Heneghan M, Aluvihare V, Agarwal K, Menon K, Vilca-Melendez H, Prachalias A, Srinivasan P, Suddle A, Rela M, Heaton N. Does donation after cardiac death utilization adversely affect hepatocellular cancer survival? Transplantation 2016;100:1916-24.

112. Orci LA, Lacotte S, Oldani G, Slits F, De Vito C, Crowe LA, Rubbia-Brandt L, Vallée JP, Morel P, Toso C. Effect of ischaemic preconditioning on recurrence of hepatocellular carcinoma in an experimental model of liver steatosis. Br J Surg 2016;103:417-26.

113. Orci LA, Lacotte S, Delaune V, Slits F, Oldani G, Lazarevic V, Rossetti C, Rubbia-Brandt L, Morel P, Toso C. Effects of the gut-liver axis on ischaemia-mediated hepatocellular carcinoma recurrence in the mouse liver. J Hepatol 2018;68:978-85.

114. Kornberg A, Witt U, Kornberg J, Friess H, Thrum K. Treating ischaemia-reperfusion injury with prostaglandin E1 reduces the risk of early hepatocellular carcinoma recurrence following liver transplantation. Aliment Pharmacol Ther 2015;42:1101-10. 
115. Goldaracena N, Barbas AS, Selzner M. Normothermic and subnormothermic ex-vivo liver perfusion in liver transplantation. Curr Opin Organ Transplant 2016;21:315-21.

116. Allard MA, Castro-Benitez C, Imai K, Selten J, Lopez A, Sebagh M, Lemoine A, Sa Cunha A, Cherqui D, Castaing D, Vibert E, Adam R. Suitability of livers for transplantation when treated by normothermic machine perfusion. Clin Transplant 2018;32:e13256.

117. Quillin RC, Guarrera JV. Hypothermic machine perfusion in liver transplantation. Liver Transpl 2018;24:276-81.

118. He X, Guo Z, Zhao Q, Ju W, Wang D, Wu L, Yang L, Ji F, Tang Y, Zhang Z, Huang S, Wang L, Zhu Z, Liu K, Zhu Y, Gao Y, Xiong W, Han M, Liao B, Chen M, Ma Y, Zhu X, Huang W, Cai C, Guan X, Li XC, Huang J. The first case of ischemia-free organ transplantation in humans: a proof of concept. Am J Transplant 2018;18:737-44.

119. Amisaki M, Saito H, Tokuyasu N, Sakamoto T, Honjo S, Fujiwara Y. Prognostic value of postoperative complication for early recurrence after curative resection of hepatocellular carcinoma. Hepatobiliary Pancreat Dis Int 2018;17:323-9.

120. Pravisani R, Baccarani U, Isola M, Adani G, Lorenzin D, Terrosu G, Risaliti A. Impact of surgical complications on the risk of hepatocellular carcinoma recurrence after hepatic resection. Updates Surg 2018;70:57-66.

121. Khandoga A, Drefs M, Schoenberg M, Schiergens T, Frenes K, Op den Winkel M, Trumm C, Angele MK, Guba M, Werner J, Rentsch M. Differential significance of early surgical complications for acute and long-term recurrence-free survival following surgical resection of hepatocellular carcinoma: do comorbidities play a role? Eur J Gastroenterol Hepatol 2017;29:1045-53.

122. Dai WC, Chok KSH, Sin SL, Chan ACY, Cheung TT, Wong TCL, Lo CM. Impact of intraoperative blood transfusion on long-term outcomes of liver transplantation for hepatocellular carcinoma. ANZ J Surg 2018;88:E418-23.

123. Elsabbagh AM, Girlanda R, Hawksworth J, Pichert MD, Williams C, Pozzi A, Kroemer A, Nookala A, Smith C, Matsumoto CS, Fishbein TM. Impact of early reoperation on graft survival after liver transplantation: univariate and multivariate analysis. Clin Transplant 2018;32:e13228.

124. Pandey CK, Singh A, Kajal K, Dhankhar M, Tandon M, Pandey VK, Karna ST. Intraoperative blood loss in orthotopic liver transplantation: the predictive factors. World J Gastrointest Surg 2015;7:86-93.

125. Teng F, Wang GH, Tao YF, Guo WY, Wang ZX, Ding GS, Shi XM, Fu ZR. Criteria-specific long-term survival prediction model for hepatocellular carcinoma patients after liver transplantation. World J Gastroenterol 2014;20:10900-7.

126. Liu B, Teng F, Fu H, Guo WY, Shi XM, Ni ZJ, Gao XG, Ma J, Fu ZR, Ding GS. Excessive intraoperative blood loss independently predicts recurrence of hepatocellular carcinoma after liver transplantation. BMC Gastroenterol 2015;15:138.

127. Kornberg A, Witt U, Kornberg J, Ceyhan GO, Mueller K, Friess H, Thrum K. Prognostic impact of intraoperative blood loss in liver transplant patients with advanced hepatocellular carcinoma. Anticancer Res 2016;36:5355-64.

128. You DD, Kim DG, Seo CH, Choi HJ, Yoo YK, Park YG. Prognostic factors after curative resection hepatocellular carcinoma and the surgeon's role. Ann Surg Treat Res 2017;93:252-9.

129. Katz SC, Shia J, Liau KH, Gonen M, Ruo L, Jarnagin WR, Fong Y, D’Angelica MI, Blumgart LH, Dematteo RP. Operative blood loss independently predicts recurrence and survival after resection of hepatocellular carcinoma. Ann Surg 2009;249:617-23.

130. Elemary M, Seghatchian J, Stakiw J, Bosch M, Sabry W, Goubran H. Transfusion challenges in hematology oncology and hematopoietic stem cell transplant - literature review and local experience. Transfus Apher Sci 2017;56:317-21.

131. Iqbal N, Haider K, Sundaram V, Radosevic J, Burnouf T, Seghatchian J, Goubran H. Red blood cell transfusion and outcome in cancer. Transfus Apher Sci 2017;56:287-90.

132. Liu L, Wang Z, Jiang S, Shao B, Liu J, Zhang S, Zhou Y, Zhou Y, Zhang Y. Perioperative allogenenic blood transfusion is associated with worse clinical outcomes for hepatocellular carcinoma: a meta-analysis. PLoS One 2013;8:e64261.

133. Seehofer D, Öllinger R, Denecke T, Schmelzle M, Andreoua A, Schott E, Pratschke J. Blood transfusions and tumor biopsy may increase HCC recurrence rates after liver transplantation. J Transplant 2017; doi: org/10.1155/2017/9731095.

134. Han S, Kim G, Ko JS, Sinn DH, Yang JD, Joh JW, Lee SK, Gwak MS. Safety of the use of blood salvage and autotransfusion during liver transplantation for hepatocellular carcinoma. Ann Surg 2016;264:339-43.

135. Zhai B, Sun XY. Controversy over the use of intraoperative blood salvage autotransfusion during liver transplantation for hepatocellular carcinoma patients. World J. Gastroenterol 2013;19:3371-4.

136. Lerut J, Iesari S, Foguenne M, Lai Q. Hepatocellular cancer and recurrence after liver transplantation: what about the impact of immunosuppression? Transl Gastroenterol Hepatol 2017;2:80.

137. Khorsandi SE, Heaton N. Optimization of immunosuppressive medication upon liver transplantation against HCC recurrence. Transl Gastroenterol Hepatol 2016;1:25.

138. Suthanthiran M, Hojo M, Maluccio M, Boffa DJ, Luan FL. Post-transplantation malignancy: a cell autonomous mechanism with implications for therapy. Trans Am Clin Climatol Assoc 2009;120:369-88.

139. Zhu H, Sun Q, Tan C, Xu M, Dai Z, Wang Z, Fan J, Zhou J. Tacrolimus promotes hepatocellular carcinoma and enhances CXCR4/SDF $1 \alpha$ expression in vivo. Mol Med Rep 2014;10:585-92.

140. Vivarelli M, Cucchetti A, Piscaglia F, La Barba G, Bolondi L, Cavallari A, Pinna AD. Analysis of risk factors for tumor recurrence after liver transplantation for hepatocellular carcinoma: key role of immunosuppression. Liver Transpl 2005;11:497-503.

141. Vivarelli M, Cucchetti A, La Barba G, Ravaioli M, Del Gaudio M, Lauro A, Grazi GL, Pinna AD. Liver transplantation for hepatocellular carcinoma under calcineurin inhibitors: reassessment of risk factors for tumor recurrence. Ann Surg 2008;248:857-62

142. Rodríguez-Perálvarez M, Tsochatzis E, Naveas MC, Pieri G, García-Caparrós C, O’Beirne J, Poyato-González A, Ferrín-Sánchez G, Montero-Álvarez JL, Patch D, Thorburn D, Briceño J, De la Mata M, Burroughs AK. Reduced exposure to calcineurin inhibitors early after liver transplantation prevents recurrence of hepatocellular carcinoma. J Hepatol 2013;59:1193-9.

143. Zaza G, Granata S, Caletti C, Signorini L, Stallone G, Lupo A. mTOR inhibition role in cellular mechanisms. Transplantation 2018;102:S316.

144. de Fijter JW. Cancer and mTOR inhibitors in transplant recipients. Transplantation 2017;101:45-55.

145. Duvoux C, Toso C. mTOR inhibitor therapy: does it prevent HCC recurrence after liver transplantation? Transplant Rev (Orlando) 
2015;29:168-74.

146. Yanik EL, Chinnakotla S, Gustafson SK, Snyder JJ, Israni AK, Segev DL, Engels EA. Effects of maintenance immunosuppression with sirolimus after liver transplant for hepatocellular carcinoma. Liver Transpl 2016;22:627-34.

147. Ferreiro AO, Vazquez-Millán MA, López FS, Gutiérrez MG, Diaz SP, Patiño MJ. Everolimus-based immunosuppression in patients with hepatocellular carcinoma at high risk of recurrence after liver transplantation: a case series. Transplant Proc 2014 46:3496-501.

148. Vivarelli M, Dazzi A, Cucchetti A, Gasbarrini A, Zanello M, Di Gioia P, Bianchi G, Tamè MR, Gaudio MD, Ravaioli M, Cescon M, Grazi GL, Pinna AD. Sirolimus in liver transplant recipients: a large single-center experience. Transplant Proc 2010;42:2579-84.

149. Liang W, Wang D, Ling X, Kao AA, Kong Y, Shang Y, Guo Z, He X. Sirolimus-based immunosuppression in liver transplantation for hepatocellular carcinoma: a meta-analysis. Liver Transpl 2012;18:62-9.

150. Menon KV, Hakeem AR, Heaton ND. Meta-analysis: recurrence and survival following the use of sirolimus in liver transplantation for hepatocellular carcinoma. Aliment Pharmacol Ther 2013;37:411-9.

151. Cholongitas E, Mamou C, Rodríguez-Castro KI, Burra P. Mammalian target of rapamycin inhibitors are associated with lower rates of hepatocellular carcinoma recurrence after liver transplantation: a systematic review. Transpl Int 2014;27:1039-49.

152. Zhang ZH, Li LX, Li P, Lv SC, Pan B, He Q. Sirolimus in liver transplant recipients with hepatocellular carcinoma: an updated metaanalysis. J Invest Surg 2018;20:1-10.

153. Geissler EK, Schnitzbauer AA, Zülke C, Lamby PE, Proneth A, Duvoux C, Burra P, Jauch KW, Rentsch M, Ganten TM, Schmidt J, Settmacher U, Heise M, Rossi G, Cillo U, Kneteman N, Adam R, van Hoek B, Bachellier P, Wolf P, Rostaing L, Bechstein WO, Rizell M, Powell J, Hidalgo E, Gugenheim J, Wolters H, Brockmann J, Roy A, Mutzbauer I, Schlitt A, Beckebaum S, Graeb C, Nadalin S, Valente U, Turrión VS, Jamieson N, Scholz T, Colledan M, Fändrich F, Becker T, Söderdahl G, Chazouillères O, Mäkisalo H, Pageaux GP, Steininger R, Soliman T, de Jong KP, Pirenne J, Margreiter R, Pratschke J, Pinna AD, Hauss J, Schreiber S, Strasser S, Klempnauer J, Troisi RI, Bhoori S, Lerut J, Bilbao I, Klein CG, Königsrainer A, Mirza DF, Otto G, Mazzaferro V, Neuhaus P, Schlitt HJ. Sirolimus use in liver transplant recipients with hepatocellular carcinoma: a randomized, multicenter, open-label phase 3 trial. Transplantation 2016;100:116-25.

154. Angelico R, Parente A, Manzia TM. Using a weaning immunosuppression protocol in liver transplantation recipients with hepatocellular carcinoma: a compromise between the risk of recurrence and the risk of rejection? Transl Gastroenterol Hepatol 2017;2:74.

155. Todo S, Yamashita K, Goto R, Zaitsu M, Nagatsu A, Oura T, Watanabe M, Aoyagi T, Suzuki T, Shimamura T, Kamiyama T, Sato N, Sugita J, Hatanaka K, Bashuda H, Habu S, Demetris AJ, Okumura K. A pilot study of operational tolerance with a regulatory T-cell-based cell therapy in living donor liver transplantation. Hepatology 2016;64:632-43.

156. de la Garza RG, Sarobe P, Merino J, Lasarte JJ, D’Avola D, Belsue V, Delgado JA, Silva L, Iñarrairaegui M, Sangro B, Sola JJ, Pardo F, Quiroga J, Herrero JI. Trial of complete weaning from immunosuppression for liver transplant recipients: factors predictive of tolerance. Liver Transpl 2013;19:937-44.

157. Manzia TM, Angelico R, Baiocchi L, Toti L, Ciano P, Palmieri G, Angelico M, Orlando G, Tisone G. The tor vergata weaning of immunosuppression protocols in stable hepatitis C virus liver transplant patients: the 10-year follow-up. Transpl Int 2013;26:259-66. 